\title{
The Cultural Heritage and the Shaping of Tourist Itineraries in Rural Areas: The Case of Historical Ensembles of Extremadura, Spain
}

\author{
José-Manuel Sánchez-Martín ${ }^{1, * \mathbb{C}}$, José-Luis Gurría-Gascón ${ }^{2} \mathbb{C}$ and María-José García-Berzosa ${ }^{1}$ \\ 1 Faculty of Business, Finance and Tourism, University of Extremadura, 10071 Cáceres, Spain; berzosa@unex.es \\ 2 Faculty of Letters, University of Extremadura, 10071 Cáceres, Spain; jlgurria@unex.es \\ * Correspondence: jmsanche@unex.es
}

Received: 10 February 2020; Accepted: 27 March 2020; Published: 27 March 2020

check for updates

\begin{abstract}
Heritage is a very complex concept that is characterized by having multiple meanings. Despite this, there is no doubt as to its attraction for carrying out tourist activities. In the specific case of cultural heritage, there is widespread agreement in considering it as a tourist resource given the interest it raises amongst visitors of all origins. This is not, however, always the case and it can be observed that in certain areas, especially rural ones, certain limitations exist. They are caused by multiple factors such as the importance of the resource itself, although the distance to the main centers of tourist attraction is also considered a key point. Due to this, the study puts forward the need for joining forces and attractions in order to create tourist itineraries based on a peculiar kind of resource: Historical Ensembles. In order to achieve this aim, we used the network analysis tools included in a geographical information system and applied it to a rural context, which was that of Extremadura in Spain. To be precise, the closest facility and service area tools were used. The results of the various analyses reflect the real possibility of generating tourist itineraries as a first step in the design of tourist products. In this way, the administration can be provided with a management tool capable of laying the foundations of a coherent and efficient tourist policy.
\end{abstract}

Keywords: cultural heritage; historical ensemble; GIS; network analyst; service area; closest facility; Extremadura

\section{Introduction}

The meaning of heritage is complex. It can be understood as anything considered worth preserving, irrespective of the value of its use. Some authors consider it to be an invention and a social construction that has an effect on multiple levels such as political, scientific, or business [1]. It also includes both tangible and intangible elements [2]. Other authors have distinguished two nuances, one related to culture and nature and the other linked to the past of a society, although it only exists when this is highlighted. The legacy is thus linked to time and the use that is made of it $[3,4]$.

In its conceptualization, the contributions that considered it to be an inheritance, a historical selection, a social identity, and a reference to the past stand out [5]. Likewise, numerous studies have treated the cultural landscape as part of heritage [6], with the main challenge being the maintaining of sustainability $[7,8]$, especially if its transformation into a tourist resource is taken into account. It is also frequently considered to be an artistic attraction when it acquires a value and a significance [9], which is very difficult to understand given its quantity, diversity, and varied quality [10].

If this heritage is converted into a resource, it can be used to promote the socioeconomic and territorial development of the areas that contain it [11]. Indeed, cultural heritage has evolved from being a historical-artistic treasure to becoming a tourist resource of obvious value for its economic 
exploitation [12]. According to this conception, it is no longer seen only as a legacy of the past and is transformed into an essential element for achieving development in very different spaces [13]. These include historical cities [14-16], intangible assets [17], and even ancient routes or roads [18-20]. All this justifies the fact that heritage is considered to be a genuine tourist resource that contributes toward development [14]. Its use as a resource may however generate conflict between its conservation and the change implied by its recreational use [21,22].

However, the transformation of heritage into a tourist resource is not easy and has been approached by many different fields [23]. There have been noteworthy reflections on heritage and tourism that have put their faith in an integrated methodology with the aim of articulating socioeconomic development [24]. Nevertheless, numerous authors have stressed that tourists mainly visit a limited number of monuments, which coincides with those with a greater presence in the media used to disseminate information about them [25]. For this reason, spaces that do not appear in leaflets, guidebooks, or other resources are ignored by tour operators and tourists from other spaces as they prefer to visit attractions with greater media exposure [25]. As a result, it is necessary to articulate a product based on the tourist attraction capacity of certain places with an outstanding heritage, and use them as centers issuing visitors toward sites in the vicinity, which also have a rich, albeit unknown, heritage.

Apart from the difficulties of converting the heritage into a resource, the impact this may have cannot be avoided from either an economic, social, or environmental perspective. Indeed, some current opinions have begun to consider this transformation as a degradation of the heritage [26], as has occurred in numerous areas. This irreverent manner of treating our natural and cultural legacy has encouraged a bid to combine tourist development and heritage conservation, linked to the longed-for sustainable tourism [27], which is of utmost necessary in some areas. However, the sustainable integration of cultural heritage and tourism is not always straightforward [28] as a purely economic vision prevails. The dilemma of whether to put faith into sustainable development or degradation is compounded by the internal struggle between conservation and change [29], which is much more evident in rural areas where development involves the appreciation of their heritage.

Numerous references have mentioned sustainable tourism, although it is also true that criticisms have been levelled at some analyses that have been carried out. Indeed, in many cases, the role of the tourist demand itself is ignored together with the tourist resources or the part played by this activity in socio-cultural progress [30,31].

The consideration of heritage as the mainstay of tourism is not new and affects a broad range of studies. These include those that consider it to be a tourist resource, although they specify a varied selection of the same [32], and others that have analyzed the various types of heritage. Among the latter, the major players are historical cities $[14,33]$, immaterial assets $[17,34]$, routes and itineraries $[18,35,36]$, gastronomy [37], etc.

Definitions of heritage vary according to the regulations of each country. In this respect, Article 334 of the Civil Code of the Kingdom of Spain reflects the variety of real property and movable property, which can be considered as part of heritage [38], although it does not specify that they are considered cultural heritage, as it simply concentrates on elements that can be owned. In order to establish a distinction that refers to cultural heritage, we must refer to Law 16/1985 of 25 June on Spanish Historical Heritage, where Article 14.1 includes that real property is considered to be not only the elements listed in Article 334 of the Spanish Civil Code, but also those elements that can be considered inseparable from the buildings and are or have been part of the same, or of their adornments. If they can be separated, however, they constitute a perfect whole that can be easily applied to other constructions or uses other than their original one, whatever the material of which they are made, and although their separation does not visibly harm the historical or artistic merit of the building to which they adhere. Moreover, it specifies in Point 2 of the same article that the real property that makes up the Spanish Historical Heritage may be declared as Historical Monuments, Gardens, Ensembles, and Sites as well as Archaeological Areas, all of which are Assets of Cultural Interest [39]. In order to make sense of 
this ruling, the Ministry of Culture and Sports in Spain has created the General Register of Assets of Cultural Interest [40] and the General Inventory of Movable Property [41], which any citizen can freely access. These search engines allow for the downloading of a basic data sheet that identifies each of the assets on it and simultaneously provides a brief description and states their legal and administrative situation.

Naturally, heritage is located in many areas with its presence and attraction being outstanding in historical cities, although this richness is also found in the rural milieu. In this sense, it can be specified that Law 45/2007 of 13 December, on the sustainable development of the rural milieu, defines in Article 3 the rural milieu as the geographical space formed by the aggregation of municipalities or lesser local entities defined by the competent administrations as having a population of less than 30,000 inhabitants and a population density of less than 100 inhabitants per $\mathrm{km}^{2}$; while a small rural municipality is considered to be one with a resident population of less than 5000 inhabitants and is located in the rural milieu [42]. The heritage present in the rural milieu has two clear orientations, culture and nature, although it is sometimes difficult to establish a clear limit between the two [43-46]. Despite this, the rural milieu tends to be associated with rural tourism, which concentrates particularly on the enjoyment of the environment [45-47] as can be gathered from the preferences declared by the rural tourists who visit Extremadura [48]. Cultural heritage may, however, play a key role in the development of these spaces [49]. Indeed, it can be observed that even in the rural milieu, a proportion of the tourists acknowledge their preference for activities strongly linked to cultural tourism [43].

The diversity of studies facilitates the treatment of varied aspects such as economic policy [50], sustainability [51,52], and even town planning [53]. Despite this, they tend to concentrate on the main historical cities; few studies have considered the rich heritage of rural settings, and even fewer have referred to the tourist exploitation of the cultural heritage in these areas. Furthermore, there is agreement in the literature on the perception of the rural environment as a genuine tourist space, which satisfies the experience of the tourist who visits it; this has been demonstrated in various spaces [54], although there are areas in which its cultural heritage is overshadowed [43].

The exploitation of heritage has popularized studies that have applied new tools and techniques with the aim of enhancing its attractiveness and consequently encouraging the attraction of new tourists. It can therefore be observed that some studies have used building information modeling (BIM) software to reproduce and rebuild important monuments of cultural heritage [55], although recourse is also had with augmented reality (AR) to promote heritage [56-59]. Nevertheless, this type of technology has been applied to monuments and sites that are clearly recognized as centers of tourist attraction, although it is not used for less visited areas. In addition, it has been observed that few specific studies exist on creating products based on tourist itineraries in areas of lesser tourist interest. Due to this circumstance, this study has chosen to generate a valid methodology for the design of itineraries to connect areas with various cultural resources with the aim of facilitating the setup of specific tourist products.

Cultural resources can be understood in a wide sense in the context of cultural landscapes, as can be inferred from the European Landscape Convention [60]. In this sense, the concept of landscape as set down in the Agreement expresses the wish to face-in a global and direct manner-the matter of the quality of the places where the population lives. This is recognized as an essential condition for individual and social welfare (understood in the physical, physiological, and intellectual sense), sustainable development, and as a resource encouraging economic activities [60] (p. 6). For this reason, it is clear that the presence of protected heritage assets is useful for promoting the socioeconomic development of outstanding areas, as occurs in rural spaces [61]. In these spaces, it is possible to find other cultural landscapes in addition to a considerable number of monuments such as dehesas [62,63] archaeological areas [64], water landscapes [65], etc. It can thus be observed that the landscape can be considered as both cultural and natural heritage, and a reason for continuous research [66]. Despite everything, it is well worth remembering that the application of the European Landscape Convention has been questioned in some cases [67]. 
Given the huge variety of historical heritage, we have had to limit our scope to a specific area, Extremadura in Spain, using a single type of real property as a reference: Historical Ensembles. In accordance with Article 15.3 of Law 13/1985 of 25 June on Historical Spanish Heritage, this consists of the grouping of real property, which makes up a continuous or dispersed unit of settlement, conditioned by a physical structure representing the evolution of a human community as it is a witness to its culture, or constitutes an asset of use and enjoyment for the group [39].

The main aim of this study consisted of determining the main centers of cultural attraction for visitors to Extremadura and creating tourist itineraries toward Historical Ensembles. In order to achieve this, it is necessary to be familiar with the motivations of tourists for travelling to this region as well as identify the most outstanding historical sites. With the use of a network analyst and its multiple possibilities, it will be possible to create different types of itineraries. The advantages of drawing up routes and their integration as a tourist product encourage the development of activity in places with relatively few overnight stays. At the same time, this approach combats the low level occupation of tourist establishments.

\section{Materials and Methods}

\subsection{The Case Study}

The study area selected for the research was Extremadura, Spain (Figure 1), an eminently rural area with the exception of the main cities of Badajoz, Cáceres, Mérida, and Plasencia.

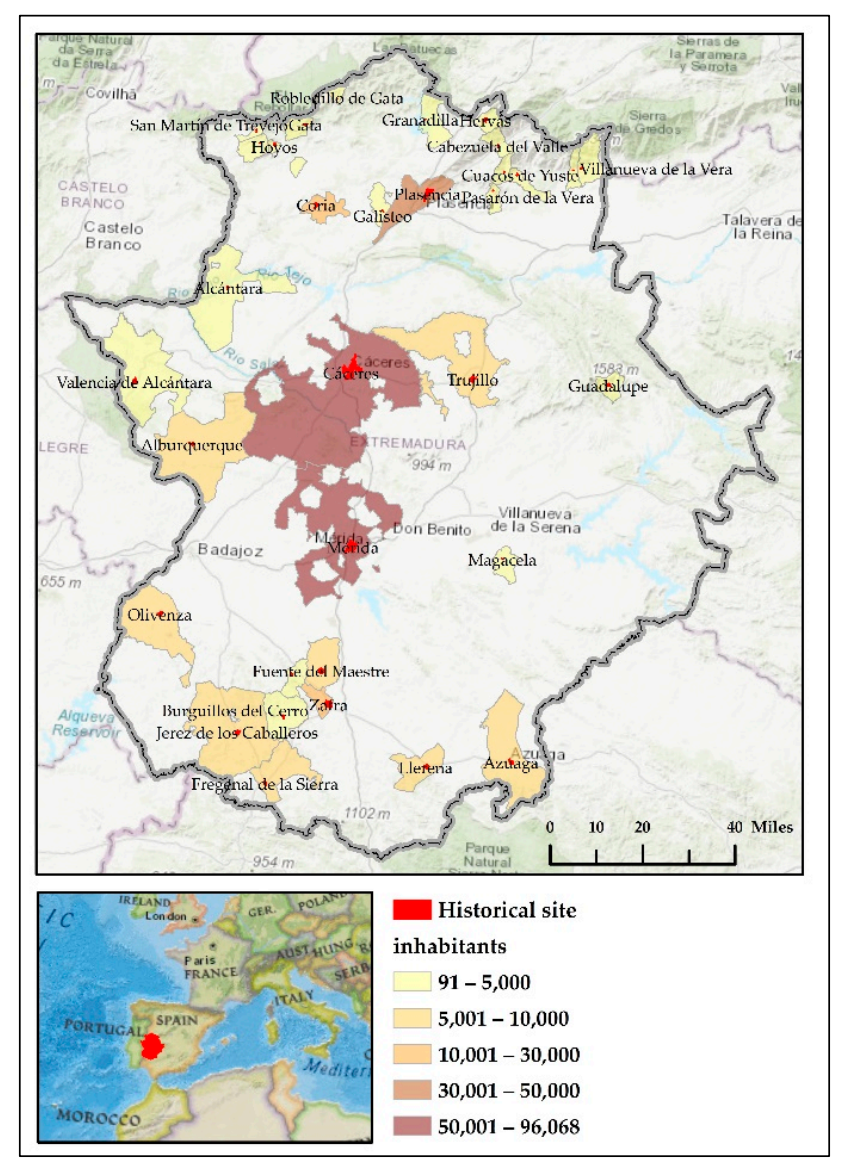

Figure 1. Location of the study area. The Historical Ensembles and their population are shown (2018).

Despite the fact that its tourist model has concentrated on cultural and natural tourism, it coincides with centers with a considerable heritage legacy [68], albeit with a clear preference for that of a cultural 
nature. This can be inferred from the publications issued periodically by the National Institute of Statistics [69], which provides information on travelers and overnight stays on its online portal (Table 1).

Table 1. Main tourist parameters in the main centers of tourist attraction in Extremadura (2018).

\begin{tabular}{|c|c|c|c|c|c|c|}
\hline \multicolumn{2}{|c|}{ Area } & Travelers & $\begin{array}{c}\text { Spanish } \\
\text { Travelers }\end{array}$ & $\begin{array}{c}\text { Foreign } \\
\text { Travelers }\end{array}$ & $\begin{array}{c}\text { Overnight } \\
\text { Stays }\end{array}$ & $\begin{array}{c}\text { Average } \\
\text { Stay }\end{array}$ \\
\hline \multicolumn{2}{|c|}{ World Heritage Cities ${ }^{1}$} & 536,348 & 437,571 & 98,777 & 836,046 & 1.56 \\
\hline \multicolumn{2}{|c|}{ Other cultural cities ${ }^{1}$} & 449.525 & 363,666 & 85,859 & 737,253 & 1.64 \\
\hline \multirow{3}{*}{$\begin{array}{l}\text { Northern area of } \\
\text { Extremadura }^{2}\end{array}$} & Hotels & 267,803 & 228,587 & 39,216 & 544,814 & 2.03 \\
\hline & $\begin{array}{c}\text { Rural } \\
\text { accommodation }\end{array}$ & 123,302 & 117,733 & 5569 & 283,149 & 2.30 \\
\hline & Camping & 71,875 & 62,511 & 9364 & 213,062 & 2.96 \\
\hline
\end{tabular}

These data from official statistics show that tourism based on the cultural heritage of Extremadura is considerable, although it is highly concentrated in the World Heritage Cities and in other towns such as Badajoz, Plasencia, Trujillo, and Zafra [70].

The National Institute of Statistics (INE) published that in 2018, and only taking the hotel sector into account, 289,496 tourists stayed in Cáceres; 246,852 in Mérida; and 209,509 in Badajoz; while Plasencia was visited by 94,665 tourists; Trujillo by 79,167 ; and Zafra by 67,194 . This volume of tourists generated in these six centers a total of 1,573,299 overnight stays, ranging from 461,629 in Cáceres to 103,367 in Zafra [69] (p.4).

This region of 16,093 square miles has 256 Assets of Cultural Interest, of which 33 are in the category of Historical Ensembles, according to the Register of Assets of Cultural Interest published by the Ministry of Culture and Sports [41]. These make up the backbone of our study.

The rich and well known heritage that characterizes these Historical Ensembles is mainly located in rural areas, with the exception of the cities that have been declared World Heritage Sites by UNESCO (Cáceres, Mérida, and Plasencia). The remainder of the 30 Historical Ensembles tend to be concentrated in certain areas such as the southwest of the province of Badajoz and the districts in the province of Cáceres of the Sierra de Gata, La Vera, and the Valle del Jerte, although they are not exclusively found in these areas.

The majority of these Historical Ensembles are among the most visited areas of Extremadura as 18 of them are centers of tourist attraction due to their high number of overnight stays. This fact is also corroborated by the number of beds that are concentrated in them. In contrast, tourists tend to visit the remainder, although they generate many overnight stays despite having various types of accommodation available (Table 2).

The study area is faced with the inherent problem of many rural areas; its heritage is not generally highlighted for organized tourist practice, but the possibility of visiting these sites is left in the hands of the tourists themselves. This circumstance does not offer a tourist experience that can be extracted from these areas, and also generates impact, conditioning their lower tourism and economic development, which affects their demography. Indeed, part of the Historical Ensembles, for which the demand does not include overnight stays or at least in the proportion seen in others, have a population of less than 1000 inhabitants. 
Table 2. Historical Ensembles: accommodation available and resident population.

\begin{tabular}{|c|c|c|c|c|c|c|}
\hline \multirow[b]{2}{*}{ Historical Ensemble } & \multirow{2}{*}{$\begin{array}{l}\text { Population } \\
\text { (2018) }\end{array}$} & \multicolumn{4}{|c|}{ Beds Available (2018) } & \multirow{2}{*}{$\begin{array}{l}\text { Is It an Important Tourist } \\
\text { Center Due to the Number o } \\
\text { Its Overnight Stays? }\end{array}$} \\
\hline & & Hotel & Non Hotel & Rural & Total & \\
\hline Alburquerque & 5340 & 51 & 0 & 33 & 84 & Yes \\
\hline Alcántara & 1480 & 118 & 0 & 34 & 152 & Yes \\
\hline Azuaga & 7891 & 102 & 27 & 14 & 143 & Yes \\
\hline Burguillos del Cerro & 3085 & 41 & 0 & 120 & 161 & No \\
\hline Cabezuela del Valle & 2151 & 46 & 64 & 97 & 207 & Yes \\
\hline Cáceres *† & 96,068 & 2481 & 1104 & 24 & 3609 & Yes \\
\hline Coria & 12,531 & 193 & 0 & 0 & 193 & Yes \\
\hline Cuacos de Yuste & 846 & 50 & 388 & 162 & 600 & No \\
\hline Feria & 1150 & 0 & 0 & 45 & 45 & No \\
\hline Fregenal de la Sierra & 4918 & 106 & 0 & 60 & 166 & No \\
\hline Fuente del Maestre & 6774 & 34 & 0 & 0 & 34 & No \\
\hline Galisteo & 953 & 43 & 8 & 0 & 51 & No \\
\hline Garganta la Olla & 984 & 12 & 0 & 59 & 71 & No \\
\hline Gata & 1493 & 24 & 6 & 42 & 72 & No \\
\hline Guadalupe ** & 1887 & 418 & 250 & 91 & 759 & Yes \\
\hline Hervás & 4052 & 225 & 1484 & 267 & 1976 & Yes \\
\hline Hoyos & 906 & 18 & 10 & 27 & 55 & No \\
\hline Jerez de los Caballeros & 9367 & 201 & 68 & 54 & 323 & Yes \\
\hline Llerena & 5758 & 148 & 0 & 52 & 200 & Yes \\
\hline Magacela & 526 & 0 & 0 & 25 & 25 & No \\
\hline Mérida *十 & 59,352 & 1844 & 649 & 12 & 2505 & Yes \\
\hline Olivenza & 11,986 & 337 & 4 & 0 & 341 & Yes \\
\hline Pasarón de la Vera & 641 & 0 & 8 & 62 & 70 & No \\
\hline Plasencia $†$ & 40,141 & 934 & 545 & 19 & 1498 & Yes \\
\hline Robledillo de Gata & 91 & 0 & 0 & 87 & 87 & No \\
\hline San Martín de Trevejo & 788 & 57 & 0 & 76 & 133 & No \\
\hline Trevejo (Villamiel) & $10(426)$ & 0 & 0 & 71 & 71 & No \\
\hline Trujillot & 9193 & 983 & 127 & 103 & 1,213 & Yes \\
\hline Valencia de Alcántara & 5439 & 112 & 12 & 235 & 359 & Yes \\
\hline Valverde de la Vera & 460 & 0 & 0 & 64 & 64 & Yes \\
\hline Villanueva de la Vera & 2046 & 20 & 39 & 137 & 196 & Yes \\
\hline Zafrat & 16,776 & 683 & 4 & 28 & 715 & Yes \\
\hline Zarza de Granadilla & 1823 & 16 & 20 & 75 & 111 & No \\
\hline
\end{tabular}

* World Heritage City; ${ }^{* *}$ World Heritage Monastery; † Most visited towns (INE 2018).

\subsection{Methodology}

The information that served as a basis for carrying out of the study comes from two well differentiated sources, depending on the type of data provided. In the first place, the cartographical information is from the National Geographical Institute (Instituto Geográfico Nacional, IGN) [71], which operates under the Creative Commons CC-BY 4.0 International License. It allows its free use for legitimate purposes with the sole obligation of acknowledging and mentioning the origin and ownership of the data. The work scale chosen was 1:100,000 as it is sufficiently detailed for the purposes of this research.

On the other hand, the information on accommodation comes from the Register of Tourist Companies of Extremadura [72], which was updated on 31 December, 2018 and makes up the database corresponding to the tourist establishments available. This alphanumeric database has been suitably georeferenced for its subsequent implementation in a geographical information system. In contrast, the information on the demand was obtained from a survey carried out throughout 2017 in tourist offices distributed all over Extremadura. This survey gathered information, which allows us to understand the structure of the demand and emphasizes the possibility of extracting a socioeconomic profile and a profile of tourist practices, among which the activity or activities that they take part in during their visit are of particular reference to this study. From these, it is easy to find out the type of tourism they practice. The following specific activities included learning Spanish; hunting; gastronomy; birdwatching; sky watching; participation in congresses or meetings; practicing sports; enjoying rivers, 
gorges, and reservoirs; practicing generic rural tourism; visiting wine cellars; visiting settings of films or TV series; visiting mines or caves and geological formations; and making cultural visits.

The methodology proposed for carrying out this study (Figure 2) starts by obtaining the necessary information from the aforementioned sources. The procedure followed concerned both the cartographic and the numerical databases. Using these data, a GIS project was generated using the ArcGIS v.10.5 software. The cartography supplied by the National Geographical Institute (IGN) was used, although it was necessary to georeference the accommodation available with the aim of including it in the geographic information system. In contrast, the data on tourist demand came from a survey carried out throughout 2017 in the tourist offices of Extremadura. The database created from this survey contained 13,848 records, which were filtered according to the tourism type practiced and considering only the 33 Historical Ensembles, which left 6167 cases in the sample. The results obtained were georeferenced on the municipality of the overnight stay, irrespective of whether it was a Historical Ensemble or not, although in this case, the starting point taken was the 39 municipalities with the highest number of answers, which ensured greater reliability and rigor.

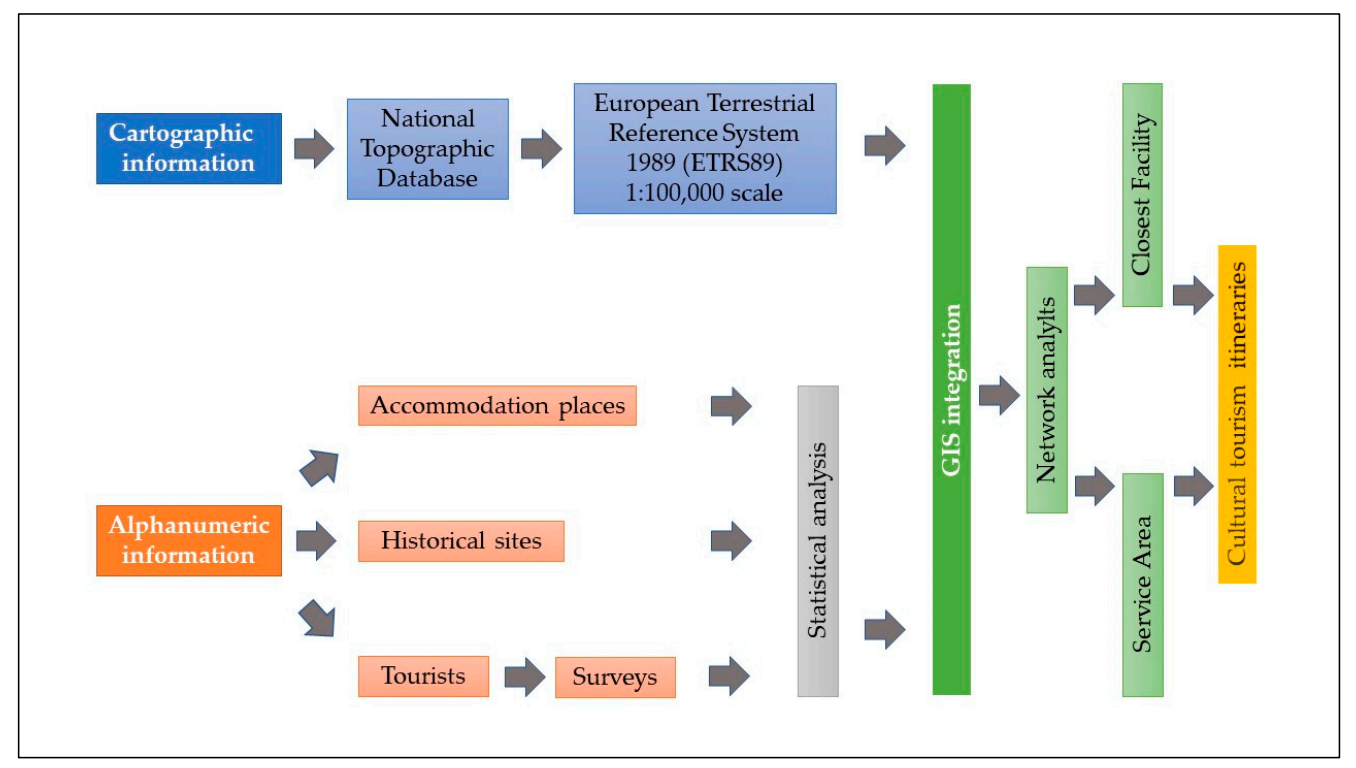

Figure 2. Methodological process.

Once the database was drawn up and passed into the geographical information system, we proceeded to determine the characteristics of the tourists who visited the protected spaces, taking into account that they must practice cultural tourism in isolation or in combination with other categories. Nevertheless, not all of these centers offered accommodation, although by means of field work, it was found that there were visitors who stayed in the vicinity. In this way, it was confirmed that Historical Ensembles were attractive to both the tourists who stayed in them and to the visitors who lodged in nearby places, as other studies on the area analyzed detected tourist mobility patterns on an isochrone of approximately $60 \mathrm{~min}[44,45]$, from which the interest of the demand gradually decreases.

After this confirmation, the possibility of creating tourist itineraries was considered by taking as a reference the most visited municipalities and the Historical Ensembles that would be viable, as it has been shown that tourist mobility patterns can be extracted [73-76]. From all of this, it can be gathered that the most visited municipalities (origin) and the Historical Ensembles (destination) were taken as a reference to establish the itineraries. In order to calculate the impedance on each of the 8969 road sections, we decided to use the most usual average legal speeds for each road type. In this manner, in the case of dual carriageways, the speed was adjusted to $120 \mathrm{~km} / \mathrm{h}(74 \mathrm{mph})$, A roads to 100 $\mathrm{Km} / \mathrm{h}$ (62 mph), and minor roads to $90 \mathrm{~km} / \mathrm{h}(55 \mathrm{mph})$, while in built-up areas, it was limited to 50 $\mathrm{km} / \mathrm{h}$ (31 mph). The impedance values obtained were corrected by means of the travel time provided 
by the Viamichelin application [77] due to its greater precision. The main criteria taken in this route generator were as follows: travelling from the center of the city of origin to the center of the city of destination; taking Sunday traffic into account; and specifying $10 \mathrm{a.m}$. as the time of departure. Once the speeds had been established and the impedance obtained for each section, we constructed the network topology on which the two techniques included in the network analysis module integrated in ArcGIS were applied. These are the service area and closest facility.

\subsubsection{Service Area}

The procedure for creating a service area from a road network has been sufficiently described in the literature [78-80] and in the assistance provided by the software used [81], although a rough outline is given in Figure $3 a, b$.
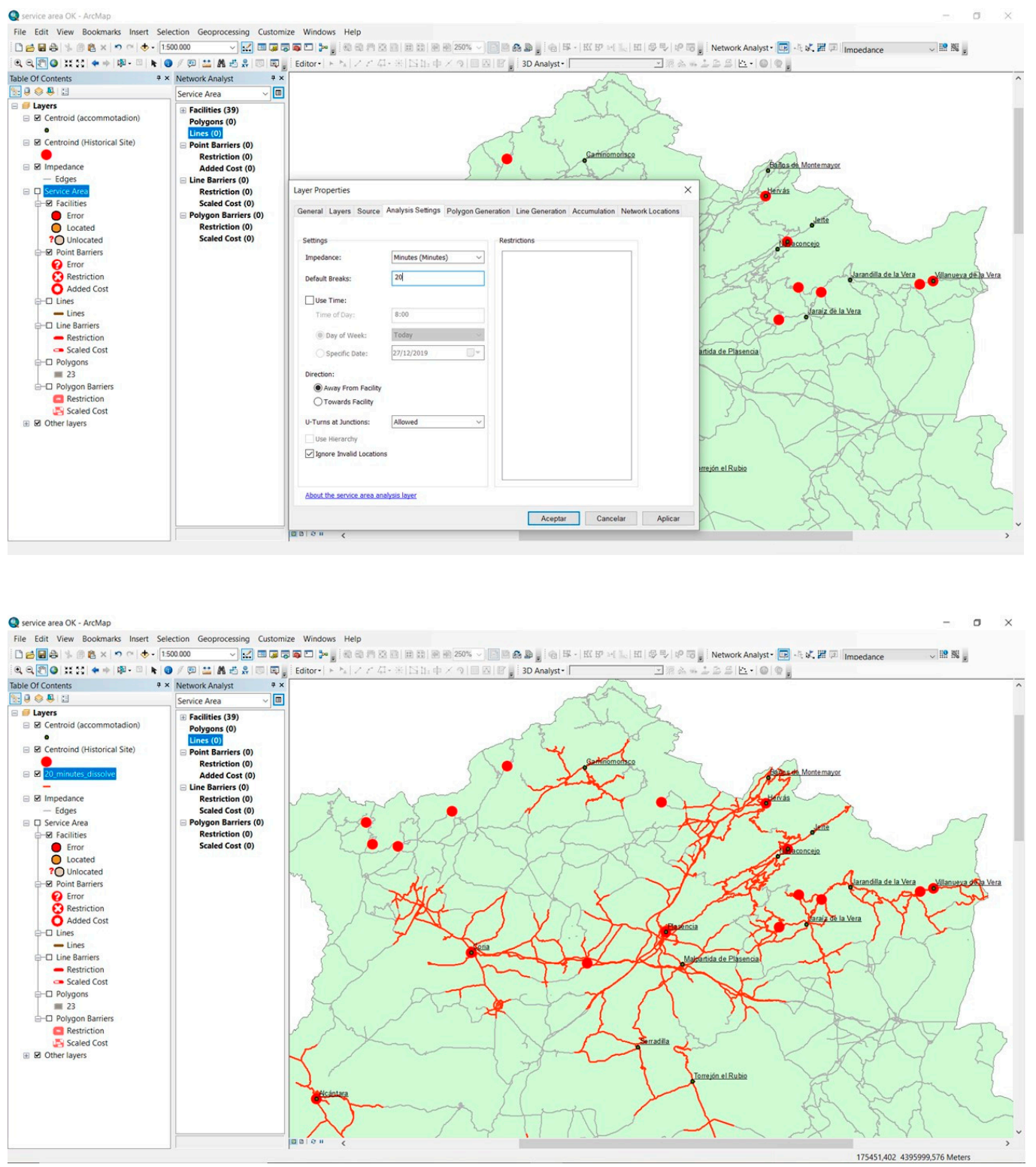

(b)

Figure 3. Example of service area operation. (a) Configuration of the analysis using an impedance of $20 \mathrm{~min}$; (b) Result (detail). It can be observed how in an isochrone of $20 \mathrm{~min}$ from the main tourist centers, there are historical ensembles that are part of one or several routes. In the same way, some more distant Historical Ensembles (northwest) can also be detected. 
The service area created on the road network allows for the obtaining of all areas and consequently of all the population centers within the isochrone specified. In order to do so, we chose to use two concentric service areas (20 and $45 \mathrm{~min}$ ) that leave from the most visited centers (origin), which allows the accessibility of each of the Historical Ensembles (destination) to be measured, most of which are located in the rural milieu. Four categories were established in all. The first refers to the most visited centers, which are also Historical Ensembles, due to which the isochrone will be 0 min when it is carried out in the population center itself. The second includes Historical Ensembles found in a center other than that of the origin, but at a distance that can be covered in $20 \mathrm{~min}$; the third category consists of those Historical Ensembles that are a maximum of $45 \mathrm{~min}$ away from the most visited centers; and finally, the fourth category consists of Historical Centers at a distance that takes over $45 \mathrm{~min}$ to cover.

The four categories described allow for the determination of the facility of access to each Historical Ensemble and also allow for the determination of the number of beds available in each of the isochrones established, and which will be part of the potential offer.

\subsubsection{Closest Facility}

The calculation of the nearest Historical Ensembles obtained the most suitable routes for travel from the main overnight stay centers, using as a criterion the two Historical Ensembles closest to the main tourist points. The technique used is a basic tool of any GIS and has a long history of scientific publications on very varied subject matters; it is very useful for showing the geographical accessibility of each site regarding certain services such as hospitals [82] or cash dispensers [83], or for calculating installations based on market sensitivity [84].

Although their use has spread as GISs have become more popular, the location of installations has been criticized because of the conception of the mathematical algorithms followed by each type of software and each application [85]. Due to this, for the purposes of this research, the algorithm integrated in ArcGIS was used.

The operation of the technique is simple as once the topology of the road network has been set up, it is only necessary to specify the number of locations near the areas of origin that must be sought (Figure $4 a, b$ ). In this case, the aim is to ascertain the two Historical Ensembles nearest to the main tourist points of Extremadura, supposing that given the average stay of less than 2 days [86], tourists cannot devote much time to internal travel.

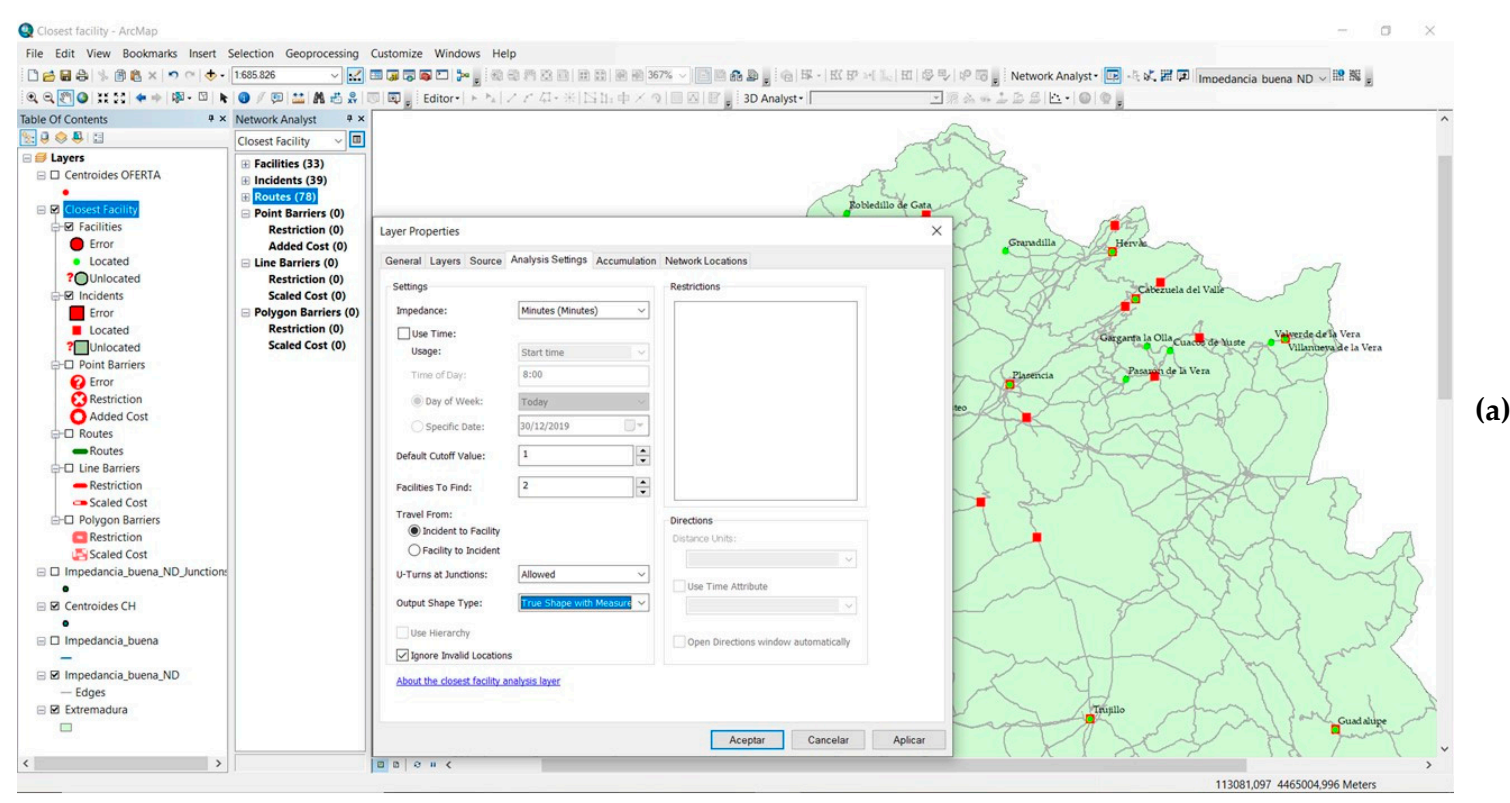

Figure 4. Cont. 


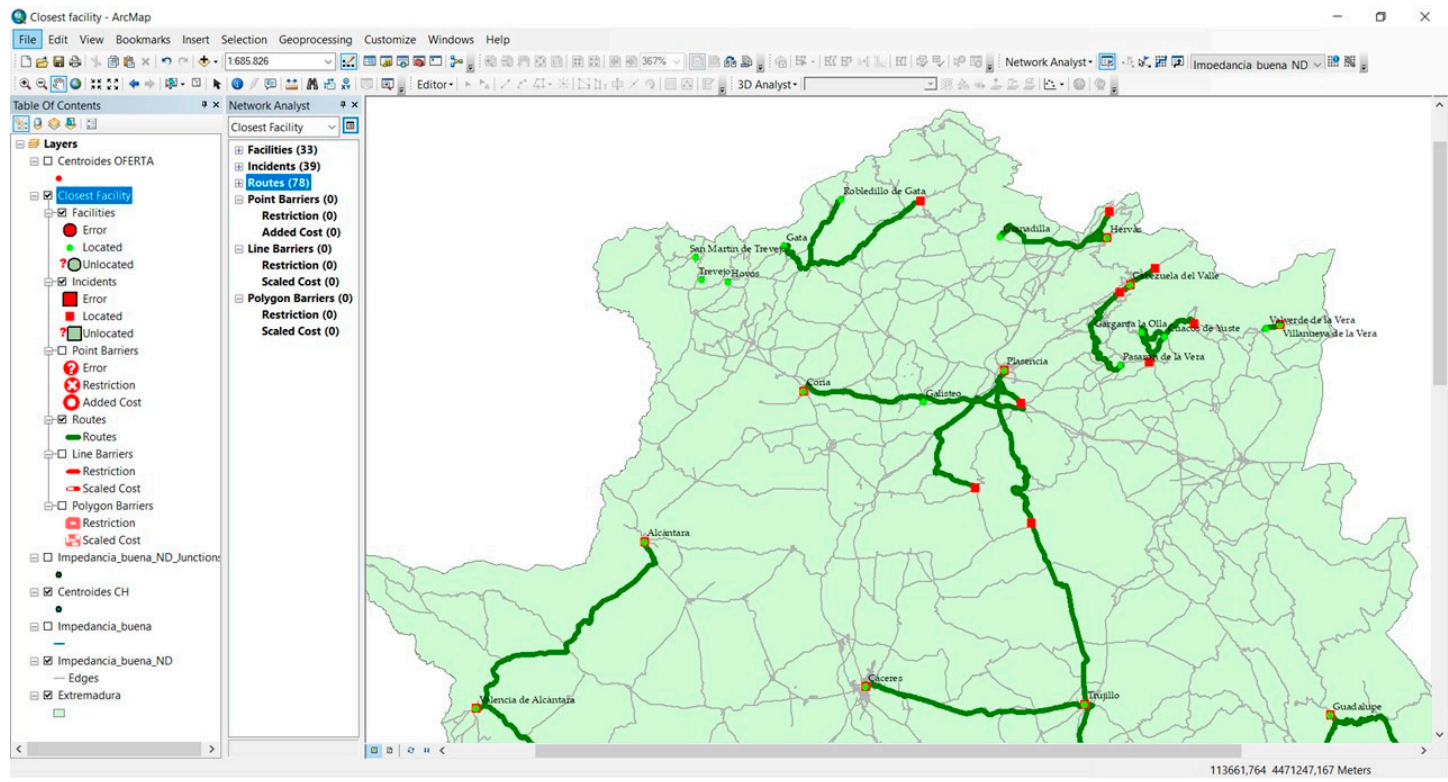

Figure 4. Example of the closest facility operation. (a) Configuration of the analysis using the two Historical Ensembles (facility) nearest the main overnight stay cities (Incident); (b) Result (detail). It can be observed how there are areas that are further away and do not enjoy the same facilities as nearer areas (northwest).

\subsubsection{The Creation of Itineraries}

The combination of the service area with the search for the nearest facilities allows for the creation of itineraries that are based on travel time and the presence of Historical Ensembles. This shows the possibilities of the combination of both techniques to put our faith in the development of itineraries as tourist products promoted from the most important overnight stay locations of Extremadura.

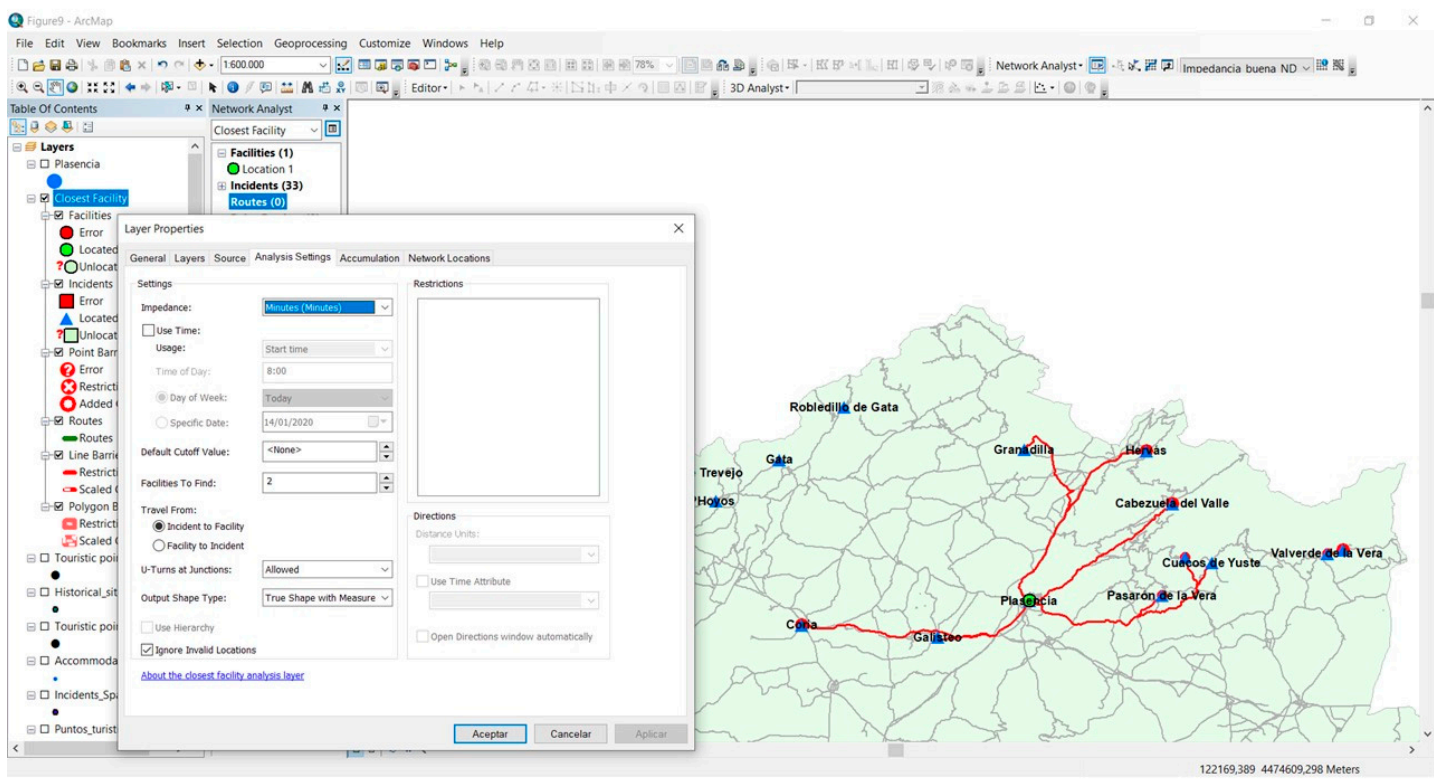

Figure 5. Example of the creation of itineraries by taking as an origin the town of Plasencia and the tourist ensembles located no more than $60 \mathrm{~min}$ travel time away as the destinations.

In order to create them, the first reference taken was the location of the main tourist points of Extremadura and subsequently, the maximum travel time to the nearest Historical Ensembles, taking the isochrone of $60 \mathrm{~min}$ as the limit (Figure 5). This spatial configuration of the network allowed for 
the creation of an initial group of itineraries concentrated on the main tourist points and a second group that started from the remainder of the important tourist centers. The main limitation is that the routes must be generated by taking a single origin with multiple destinations. Due to this, in order to establish them correctly, we took each of the tourist points as an origin and all of the Historical Ensembles as destinations.

\section{Results}

\subsection{Tourist Types}

The type of visitor received by Extremadura is very varied, although there is a predomination of those practicing cultural tourism in places where the heritage is considerable. In contrast, rural tourism predominates in upland areas and their vicinity, or in the major protected areas of the region. A clear relationship can therefore be observed between the type of resource that is characteristic of a space and the type of tourist it attracts.

Both types of tourist can be differentiated from the activities each carries out and their relationship measured by means of Pearson's linear correlation coefficient (Table 3).

Table 3. Correlations between activities carried out by cultural tourists.

\begin{tabular}{|c|c|c|c|c|c|c|c|c|c|c|c|c|c|}
\hline & $\mathrm{X} 1$ & $\mathrm{X} 2$ & $\mathrm{X} 3$ & $\mathrm{X} 4$ & $\mathrm{X} 5$ & $\mathrm{X} 6$ & $\mathrm{X} 7$ & $\mathrm{X} 8$ & X9 & X10 & X11 & X12 & X13 \\
\hline $\mathrm{X} 1$ & 1 & & & & & & & & & & & & \\
\hline $\mathrm{X} 2$ & 0.029 ** & 1 & & & & & & & & & & & \\
\hline $\mathrm{X} 3$ & 0.044 ** & 0.035 ** & 1 & & & & & & & & & & \\
\hline X5 & 0.051 ** & $0.047^{* *}$ & $0.082^{* *}$ & $0.175^{* *}$ & 1 & & & & & & & & \\
\hline X6 & -0.003 & $0.041 * *$ & $-0.042 * *$ & -0.031 ** & 0.028 ** & 1 & & & & & & & \\
\hline X7 & 0.027 ** & 0.009 & 0.007 & $0.048^{* *}$ & $0.077^{* *}$ & -0.010 & 1 & & & & & & \\
\hline X8 & $0.019 *$ & 0.004 & $0.055^{* *}$ & $0.157 * *$ & $0.117^{* *}$ & $-0.057 * *$ & $0.051 * *$ & 1 & & & & & \\
\hline X11 & $0.053^{* *}$ & $0.034^{* *}$ & $0.076^{* *}$ & $0.050 * *$ & $0.088^{* *}$ & 0.001 & 0.011 & $0.048^{* *}$ & 0.003 & $0.046^{* *}$ & 1 & & \\
\hline $\mathrm{X} 12$ & $0.027 * *$ & $0.038 * *$ & $0.047 * *$ & $0.084 * *$ & $0.099 * *$ & -0.003 & $0.026^{* *}$ & $0.110 * *$ & $0.070 * *$ & 0.117 ** & $0.029 * *$ & 1 & \\
\hline $\mathrm{X} 13$ & 0.019 * & -0.030 ** & $0.145^{* *}$ & $-0.037^{* *}$ & -0.012 & $-0.097^{* *}$ & $-0.096^{* *}$ & $-0.027^{* *}$ & $-0.099 * *$ & $0.052 * *$ & $0.028 * *$ & 0.016 & 1 \\
\hline
\end{tabular}

Learning Spanish (X1); Hunting (X2); Gastronomy (X3); Birdwatching (X4); Sky watching (X5); Participating in events (congresses or meetings) (X6); Practicing sport (X7); Tourism in rivers and gorges or reservoirs (X8);Rural tourism (X9); Visiting wine cellars (X10); Visiting settings of films or TV series (X11); Visiting mines or caves and geological formations (X12); Cultural visits (X13). ${ }^{*}$ Correlation is significant at the 0.05 level; ${ }^{* *}$ Correlation is significant at the 0.01 level.

Despite the fact that cultural tourism was defined during the $22^{\text {nd }}$ Session of the General Assembly held in Chengdu, China (11-16 September 2017) as "A type of tourism activity in which the visitor's essential motivation is to learn, discover, experience and consume the tangible and intangible cultural attractions/products in a tourism destination. These attractions/products relate to a set of distinctive material, intellectual, spiritual and emotional features of a society that encompasses arts and architecture, historical and cultural heritage, culinary heritage, literature, music, creative industries and the living cultures with their lifestyles, value systems, beliefs and traditions", defining cultural tourism is not always easy [87].

The tourist profile can be obtained from the activities they carry out. In this way, the cultural tourist is a visitor who wishes to learn Spanish, seeks gastronomic opportunities, participates in events such as congresses, visits wine cellars or film settings, and naturally makes cultural visits. In contrast, the rural tourist can be defined as one who practices hunting, birdwatching or sky watching, sports, or enjoys activities in rivers and reservoirs, in addition to those who practice genetic rural tourism or visit geological formations.

The territorial distribution of both generic tourist types in the case of the most visited destinations reflects the fact that in certain places, the proximity of the heritage resource does not coincide with a high percentage of those practicing cultural tourism (Figure 6). There are areas in the north of the province of Cáceres in which cultural tourism is not so important, despite the presence of a considerable cultural heritage. This situation is due to the fact that these areas have outstanding 
natural resources and are particularly orientated toward summer tourism because they have bathing areas and milder temperatures, complemented by important marketing campaigns and the proximity to large centers generating tourists such as Madrid [48]. In other areas, there is a noticeable balance between cultural and rural tourism, as is the case in the Villuercas-lbores-Jara Geopark, exemplified by the centers of Cañamero and Guadalupe. In contrast, the province of Badajoz is characterized by a clear predominance of cultural tourism. From all of this, two interesting aspects can be inferred. The first is the diversity of activities carried out by rural tourists, which may serve as a basis for integrating them in a potential tourist product as occurs with gastronomy, for example. The second is based on the territorial diversity of rural tourists who predominate in some areas, rather than in others.

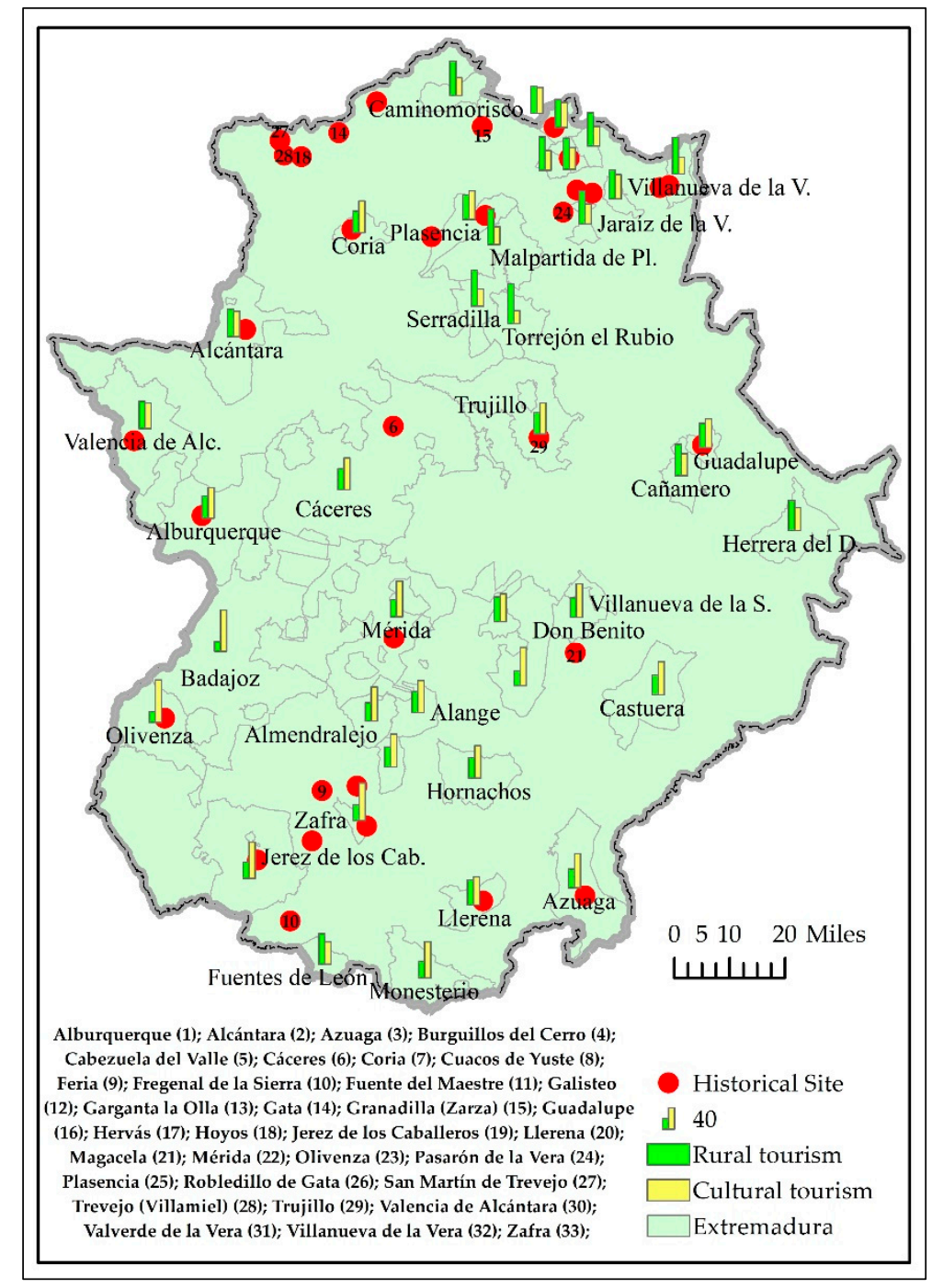

Figure 6. Distribution of the dominant tourist types at the main tourist points.

\subsection{Historical Ensembles as Potential Centers for Attracting Demand (Service Area)}

Historical Ensembles act as true centers of tourist attractions. However, their capacity to attract visitors lies in their proximity to the main centers of tourist attraction in Extremadura, in addition to their importance and the confluence of further recognition by the Ministry of Culture and UNESCO. For this reason, the service area was calculated with two different isochrones corresponding to one-way travel lasting 20 and $45 \mathrm{~min}$. Moreover, it should be pointed out that certain Historical Ensembles coincide with the most visited centers; in these cases, the travel time was considered to be zero. Likewise we included all centers that are Historical Ensembles, but at a greater travel distance. Four 
categories were therefore recognized according to the travel time from the most important tourist centers (Table 4).

Table 4. Isochrones and Historical Ensembles.

\begin{tabular}{|c|c|c|c|}
\hline $\begin{array}{l}\text { Category } 1 \\
(0 \text { min })\end{array}$ & $\begin{array}{l}\text { Category } 2 \\
(20 \text { min })\end{array}$ & $\begin{array}{l}\text { Category } 3 \\
(45 \mathrm{~min})\end{array}$ & $\begin{array}{c}\text { Category } 4 \\
\text { (More than } 45 \mathrm{~min} \text { ) }\end{array}$ \\
\hline $\begin{array}{c}\text { Alburquerque } \\
\text { Alcántara } \\
\text { Azuaga } \\
\text { Cabezuela del Valle } \\
\text { Cáceres } \\
\text { Coria } \\
\text { Guadalupe } \\
\text { Hervás } \\
\text { Jerez de los Caballeros } \\
\text { Llerena } \\
\text { Mérida } \\
\text { Olivenza } \\
\text { Plasencia } \\
\text { Trujillo } \\
\text { Valencia de Alcántara } \\
\text { Villanueva de la Vera } \\
\text { Zafra }\end{array}$ & $\begin{array}{c}\text { Garganta la Olla } \\
\text { Pasarón de la Vera } \\
\text { Valverde de la Vera }\end{array}$ & $\begin{array}{c}\text { Burguillos del Cerro } \\
\text { Feria } \\
\text { Hoyos }\end{array}$ & $\begin{array}{c}\text { Cuacos de Yuste } \\
\text { Fregenal de la Sierra } \\
\text { Fuente del Maestre } \\
\text { Galisteo } \\
\text { Gata } \\
\text { Granadilla } \\
\text { Magacela } \\
\text { Robledillo de Gata } \\
\text { San Martín de Trevejo } \\
\text { Trevejo }\end{array}$ \\
\hline
\end{tabular}

There are a large number of Historical Ensembles scattered over a large proportion of Extremadura (Figure 7), of which 17 (51.5\%) are among the most popular tourist destinations of Extremadura and make up category 1 . Indeed, it is made up of the population centers receiving most of the tourists and that have a Historical Ensemble. Among them, Cáceres and Mérida stand out as both have been declared World Heritage Sites as well as Guadalupe, as its monastery is part of this same Heritage. Together with other towns such as Plasencia, Trujillo, Zafra, Jerez de los Caballeros, and Hervás, they are icons of the rich cultural legacy of Extremadura and attract many visitors. It was found that during 2018, if we only included the statistics of the hotel accommodation at the main tourist points, the city of Cáceres was visited by 289,496 people, Mérida by 246,852 , and Badajoz by 209,509, while Plasencia, Trujillo, and Zafra attracted less than 100,000 travelers [86]. Evidently, a large proportion of these population centers is attractive to tourists and day trippers, with the outstanding cities that are World Heritage Sites, although in others that are smaller and less attractive, tourist itineraries could be drawn up to connect them with other centers that also have quality tourist resources.

Category 2 is made up of the Historical Ensembles that are located no more than 20 min away from the main tourist centers. It contains three Historical Ensembles: Garganta la Olla, Pasarón de la Vera, and Valverde de la Vera, with a travel time between them of $56 \mathrm{~min}$ and on which route or in the vicinity of which are found other centers such as Cuacos de Yuste and Villanueva de la Vera.

Category 3 is made up of centers that are rather further away and included in the isochrone of $45 \mathrm{~min}$. These are the Historical Ensembles of Burguillos del Cerro, Feria, and Hoyos, which are far from each other, but are near other areas that receive many visitors.

Finally, Category 4 consists of 10 centers at a distance of over 45 min from the main cultural tourist destinations of Extremadura. Despite this, they are very attractive and are equally close to other Historical Ensembles, which increases their attraction, provided that a circuit or tourist itinerary is generated and enhanced by means of a cultural tourist product. 


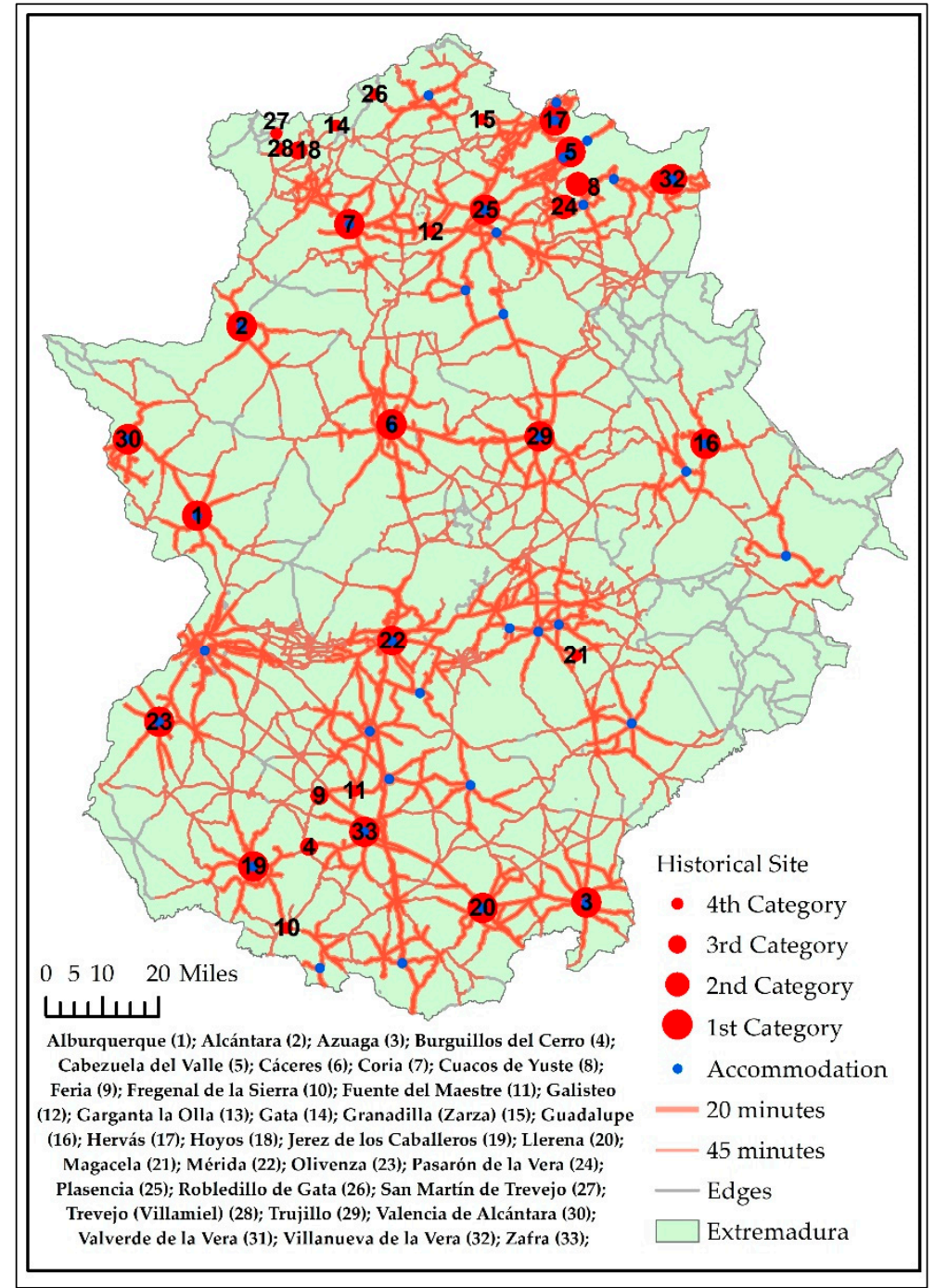

Figure 7. Isochrones obtained by means of the service area in order to determine the capacity of attraction of the Historical Ensembles on the main tourist centers of Extremadura.

The beds available in the various types of accommodation present in the categories drawn up reflect two outstanding aspects (Table 5). In the first place, it corroborated that there is a large pool of lodgings in the municipalities that have a Historical Ensemble. They accounted for $39.8 \%$ of the total number of beds, however, the figure for hotel accommodation was over $48 \%$, non-hotel accommodation was $36.2 \%$, and rural accommodation was scarcely $26 \%$. Despite the fact that we were concerned with a high number of beds in only 33 municipalities of the 388 in Extremadura, it should be stressed that three of them (Cáceres, Mérida, and Plasencia) accumulated 46.7\% of the beds of the same. Second, it was detected that $17.3 \%$ of the beds available in rural accommodation located in municipalities that have been declared Historical Ensembles were less than $45 \mathrm{~min}$ travel time by road from the main overnight stay centers, a percentage that rises to $28.4 \%$ of the rural accommodation available when the isochrone of $45 \mathrm{~min}$ is exceeded.

Analysis of the service areas revealed that there were a large number of beds in the historical ensembles near the most visited tourist points of Extremadura. This proximity allows for the offering of specific products in the form of tourist itineraries, which could increase the percentage of occupation of the establishments, which in the case of rural accommodation in 2018 was $18.13 \%$ and $34.75 \%$ on the weekend. Likewise, the level of occupation of hotels could be increased (their average figures varied 
between $36.24 \%$ and $47.06 \%$ ), or even that of tourist apartments, which have an average occupation rate of $34.12 \%$ [86].

Table 5. Accommodation and beds available in categories.

\begin{tabular}{|c|c|c|c|c|c|c|c|c|}
\hline \multirow[b]{2}{*}{ Category } & \multicolumn{2}{|c|}{ Hotel Sector } & \multicolumn{2}{|c|}{ Non Hotel Sector } & \multicolumn{2}{|c|}{ Rural Sector } & \multicolumn{2}{|l|}{ Total } \\
\hline & Accom-Modation & Beds & Accom-Modation & Beds & Accom-Modation & Beds & Accom-Modation & Beds \\
\hline 1 & 153 & 7962 & 177 & 3832 & 104 & 1181 & 434 & 12,975 \\
\hline 2 & 1 & 12 & 1 & 8 & 13 & 185 & 15 & 205 \\
\hline 3 & 4 & 59 & 2 & 10 & 13 & 192 & 19 & 261 \\
\hline 4 & 25 & 1264 & 26 & 967 & 68 & 617 & 119 & 2848 \\
\hline $\begin{array}{l}\Sigma \text { Historical } \\
\text { Ensembles }\end{array}$ & 183 & 9297 & 206 & 4817 & 198 & 2175 & 587 & 16,289 \\
\hline $\begin{array}{l}\sum \text { HE Cáceres, } \\
\text { Mérida, and } \\
\text { Plasencia }\end{array}$ & 78 & 5259 & 153 & 2298 & 5 & 55 & 236 & 7612 \\
\hline $\begin{array}{l}\text { \% Historical } \\
\text { Ensembles }\end{array}$ & $40.6 \%$ & $48.3 \%$ & $60.1 \%$ & $36.2 \%$ & $24.8 \%$ & $26.0 \%$ & $36.9 \%$ & $39.8 \%$ \\
\hline $\begin{array}{l}\sum \text { Rest of } \\
\text { Extremadura }\end{array}$ & 268 & 9971 & 137 & 8484 & 599 & 6203 & 1004 & 24,658 \\
\hline$\Sigma$ Extremadura & 451 & 19,268 & 343 & 13,301 & 797 & 8378 & 1591 & 40,947 \\
\hline
\end{tabular}

\subsection{Nearby Historical Ensembles as Areas of Expansion for the Tourist Experience (Closest Facility)}

Numerous authors have shown that tourists move about the area near their overnight stay site $[43,45,88,89]$ and between various destinations [90,91]. In this sense, the existence has been demonstrated of Historical Ensembles, which have the competitive advantage of being located close to the main tourist points of Extremadura. At the same time, it has been corroborated that there are other centers that lack these advantages as they are located on an isochrone exceeding 45 min of travel time, which would place them at the limit of the mobility that the tourist can assume, as has been found by some studies that revealed a considerable drop in the arrival of visitors from the main destinations when travel time exceeded $60 \mathrm{~min}$. It is in these cases, when outgoing or return journeys to their places of residence are made use of to make short stops in these areas [45]. Due to this, it is interesting to design tourist itineraries capable of attracting visitors from the vicinity and to expand the economic benefits generated by tourism, especially when these other destinations are located in the rural milieu with the added problems that this entails.

Under these premises, it was decided to determine whether tourists stayed about two days in the accommodation establishments located in the main tourist areas [92] and they did not go far to explore the vicinity. For this reason, the Historical Ensembles closest to the overnight stay site were found, even though half of them coincided with the most visited sites.

The most significant results obtained with the closest facility application imply that there were 78 possible routes from the overnight stay points (39) to the two nearest Historical Ensembles (33) (Table 6).

A detailed analysis of the Historical Ensembles close to the most important tourist centers shows that in addition to the 17 that coincided with the most visited centers, there were 45 possible routes located at the limit of the isochrone of $45 \mathrm{~min}$. Moreover, it is logical to think that the nearest were those with the best opportunities for receiving visitors. On the other hand, there were 16 other possible routes with a travel time exceeding the threshold of $45 \mathrm{~min}$. It is therefore feasible to design historical itineraries to link the most visited municipalities with Historical Ensembles in a reasonable time for tourists, thus encouraging the development of the adjoining areas (Figure 8). 
Table 6. Routes obtained between the tourist points and the two nearest Historical Ensembles *.

\begin{tabular}{|c|c|c|c|c|c|}
\hline Tourist Points & $\begin{array}{l}\text { Historical } \\
\text { Ensemble }\end{array}$ & Minutes & Tourist Points & Historical Ensemble & Minutes \\
\hline Villanueva de la Vera & Valverde de la Vera & 4 & $\begin{array}{l}\text { Jarandilla de la } \\
\text { Vera }\end{array}$ & Garganta la Olla & 26 \\
\hline Navaconcejo & Cabezuela del Valle & 5 & Hervás & Granadilla & 27 \\
\hline Jerte & Cabezuela del Valle & 7 & Azuaga & Llerena & 29 \\
\hline Baños de Montemayor & Hervás & 8 & Badajoz & Olivenza & 29 \\
\hline Jaraíz de la Vera & Cuacos de Yuste & 10 & $\begin{array}{l}\text { Baños de } \\
\text { Montemayor }\end{array}$ & Granadilla & 29 \\
\hline Jaraíz de la Vera & Garganta la Olla & 10 & Llerena & Azuaga & 29 \\
\hline Villanueva de la Serena & Magacela & 13 & Monesterio & Zafra & 32 \\
\hline Jarandilla de la Vera & Cuacos de Yuste & 14 & Castuera & Magacela & 34 \\
\hline $\begin{array}{l}\text { Villafranca de los } \\
\text { Barros }\end{array}$ & Fuente del Maestre & 14 & Monesterio & Llerena & 35 \\
\hline $\begin{array}{l}\text { Malpartida de } \\
\text { Plasencia }\end{array}$ & Galisteo & 15 & Alburquerque & Valencia de Alcántara & 36 \\
\hline $\begin{array}{l}\text { Malpartida de } \\
\text { Plasencia }\end{array}$ & Plasencia & 16 & Medellín & Mérida & 36 \\
\hline Zafra & Fuente del Maestre & 16 & Torrejón el Rubio & Trujillo & 36 \\
\hline Don Benito & Magacela & 17 & $\begin{array}{l}\text { Valencia de } \\
\text { Alcántara }\end{array}$ & Alburquerque & 36 \\
\hline Cañamero & Guadalupe & 19 & Serradilla & Galisteo & 38 \\
\hline $\begin{array}{l}\text { Villafranca de los } \\
\text { Barros }\end{array}$ & Zafra & 20 & Hornachos & Zafra & 39 \\
\hline Coria & Galisteo & 21 & Mérida & Fuente del Maestre & 39 \\
\hline Jerez de los Caballeros & $\begin{array}{l}\text { Burguillos del } \\
\text { Cerro }\end{array}$ & 21 & Alange & Fuente del Maestre & 41 \\
\hline Almendralejo & Fuente del Maestre & 22 & Hornachos & Fuente del Maestre & 41 \\
\hline Plasencia & Galisteo & 22 & Navaconcejo & Pasarón de la Vera & 41 \\
\hline Fuentes de León & $\begin{array}{l}\text { Fregenal de la } \\
\text { Sierra }\end{array}$ & 23 & Serradilla & Plasencia & 41 \\
\hline Almendralejo & Mérida & 24 & Fuentes de León & Jerez de los Caballeros & 43 \\
\hline Alange & Mérida & 25 & Caminomorisco & Gata & 45 \\
\hline Medellín & Magacela & 25 & & & \\
\hline
\end{tabular}

${ }^{*}$ Neither the Historical Ensembles coinciding with the most visited tourist points nor those further away than the isochrone of $45 \mathrm{~min}$ were included as routes

The main tourist centers, having a heritage considered to be a Historical Ensemble, are in a better position to generate a tourist route, especially if another center with a considerable cultural heritage lies in the vicinity. In this sense, the most favored are: Alburquerque, Alcántara, Azuaga, Cabezuela del Valle, Cáceres, Coria, Guadalupe, Hervás, Jerez de los Caballeros, Llerena, Mérida, Olivenza, Plasencia, Trujillo, Valencia de Alcántara, Villanueva de la Vera, and Zafra. These historical ensembles are capable of attracting numerous visitors on their own accord, although Cáceres, Mérida, Trujillo, and Plasencia stand out for their capacity of attraction. Moreover, it so happens that some of them are also located on the isochrone of $20 \mathrm{~min}$ from others, as is the case of Cabezuela del Valle, Guadalupe, Hervás, Plasencia, and Zafra. In other words, these centers have their own Historical Ensemble and another very close to it to take advantage of the territorial synergies that tourist activities allow.

Other municipalities that have a historical ensemble, but are not among the most visited are, however, no more than 20 min by car from the main tourist points of Extremadura, which can bring them visitors who spend the night nearby. These include Cuacos de Yuste, Fuente del Maestre, Galisteo, Garganta la Olla, Magacela, and Valverde de la Vera. This group of towns is accompanied by others that are more than $20 \mathrm{~min}$ from the most visited centers, although they are not more than $45 \mathrm{~min}$ away by car. These are Burguillos del Cerro, Fregenal de la Sierra, Fuente del Maestre, Galisteo, Garganta la Olla, Gata, Granadilla, Llerena, Pasarón de la Vera, Trujillo, and Valencia de Alcántara. 


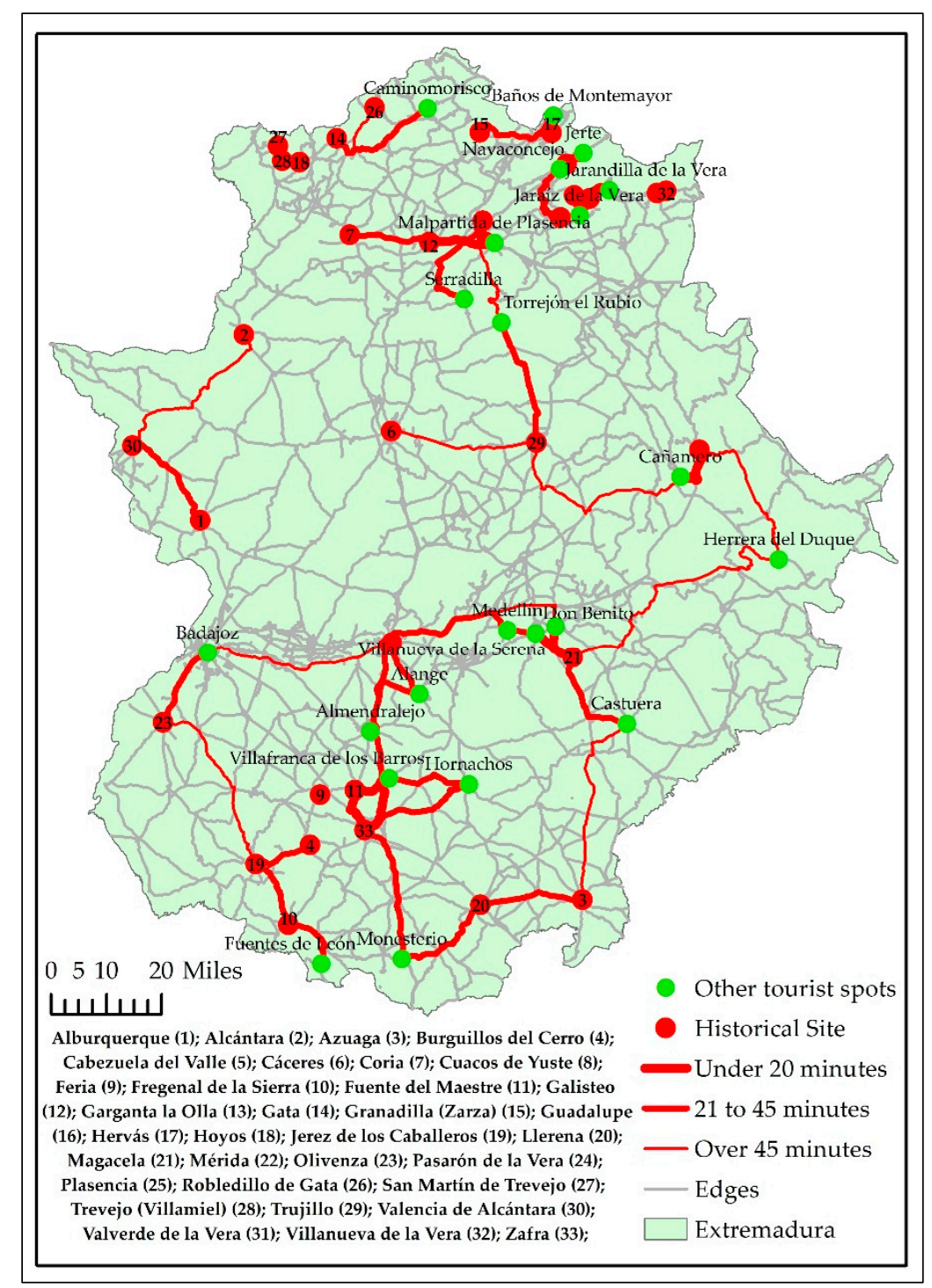

Figure 8. Historical Ensembles near the most outstanding tourist points obtained by means of closest facility.

This analysis emphasizes the existence of various competitive advantages among the historical ensembles, always taking into account the proximity to the most popular tourist centers. This would facilitate the creation of specific routes orientated toward excursions.

\subsection{Designing Cultural Itineraries in the Rural Milieu}

The use of the service area and closest facility shows that there are genuine possibilities of creating tourist itineraries directed from each of the most visited centers toward the Historical Ensembles. The starting point is that of itineraries combining duration and the number of possible destinations, taking into account the time available as the average stay tends to be less than two days [85].

In order to make the calculation, we took as a reference a maximum distance of $60 \mathrm{~min}$ from the center of each tourist point to the center of each Historical Ensemble. The result was 116 possible routes starting from a total of 22 tourist points and leading toward 31 Historical Ensembles, some of which were outside the isochrone established.

The Historical Ensembles that can most benefit from the creation of tourist itineraries are those linked to the tourist points that capture the most demand and are the nearest. These were Cáceres, Mérida, Badajoz, Plasencia, Trujillo, and Zafra (Table 7). 
Table 7. Primary itineraries.

\begin{tabular}{|c|c|c|c|c|c|}
\hline 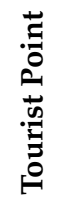 & $\begin{array}{l}\text { Historical } \\
\text { Ensemble }\end{array}$ & Minutes & 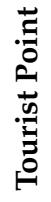 & Historical Ensemble & Minutes \\
\hline \multirow{5}{*}{$\frac{N}{\frac{N}{\pi}}$} & Olivenza & 29 & \multirow{9}{*}{ 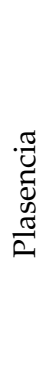 } & Plasencia & 0 \\
\hline & Alburquerque & 44 & & Galisteo & 20 \\
\hline & Mérida & 45 & & Pasarón de la Vera & 32 \\
\hline & Feria & 54 & & Hervás & 34 \\
\hline & Fuente del Maestre & 60 & & Coria & 35 \\
\hline \multirow{3}{*}{ 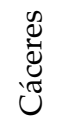 } & Cáceres & 0 & & Cabezuela del Valle & 38 \\
\hline & & & & Granadilla & 40 \\
\hline & Trujillo & 48 & & Cuacos de Yuste & 49 \\
\hline \multirow{5}{*}{$\frac{\sqrt[\pi]{0}}{\stackrel{0}{0}}$} & Mérida & 0 & & Garganta la Olla & 49 \\
\hline & Fuente del Maestre & 40 & \multirow{8}{*}{$\underset{\mathbb{N}}{\stackrel{\pi}{N}}$} & Zafra & 0 \\
\hline & Zafra & 45 & & Fuente del Maestre & 15 \\
\hline & Feria & 56 & & Burguillos del Cerro & 19 \\
\hline & Magacela & 60 & & Feria & 19 \\
\hline \multirow{4}{*}{$\stackrel{\circ}{:=}$} & Trujillo & 0 & & Llerena & 38 \\
\hline & Cáceres & 48 & & Fregenal de la Sierra & 39 \\
\hline & Magacela & 58 & & Jerez de los Caballeros & 39 \\
\hline & & & & Mérida & 45 \\
\hline
\end{tabular}

Their territorial distribution (Figure 9) shows that with the exception of Badajoz, they had a Historical Ensemble. At the same time, it was observed that some centers can offer a considerable number of itineraries, as is the case of Plasencia or Zafra. These towns also generate itineraries that can even reach two Historical Ensembles on the same route, with the advantages that this brings when creating a specific tourist product.

The 32 itineraries created have a different development and success potential as in some cases, a Historical Ensemble is also a World Heritage Site. In other cases, the attraction of the historical site itself is different, to which must be added other elements such as the reputation of the area in which it is located and naturally the travel time.

Any of the routes including the cities of Cáceres or Mérida are clearly more attractive, with Trujillo being the center, which benefits most, given its proximity to Cáceres. Travel time must also be taken into account as the nearest ensembles will be those with the most competitive advantages. In this case, Plasencia, one of the most visited centers of Extremadura, can generate itineraries with some $30 \mathrm{~min}$ of travel time to Galisteo and Coria as well as to Pasarón de la Vera, Hervás, and Cabezuela del Valle, which are also outstanding tourist destinations. A similar situation can be found in Zafra, with the nearby sites of Fuente del Maestre, Burguillos del Cerro, and Feria, in addition to those of Llerena, Fregenal de la Sierra, and Jerez de los Caballeros, which are rather further away. 


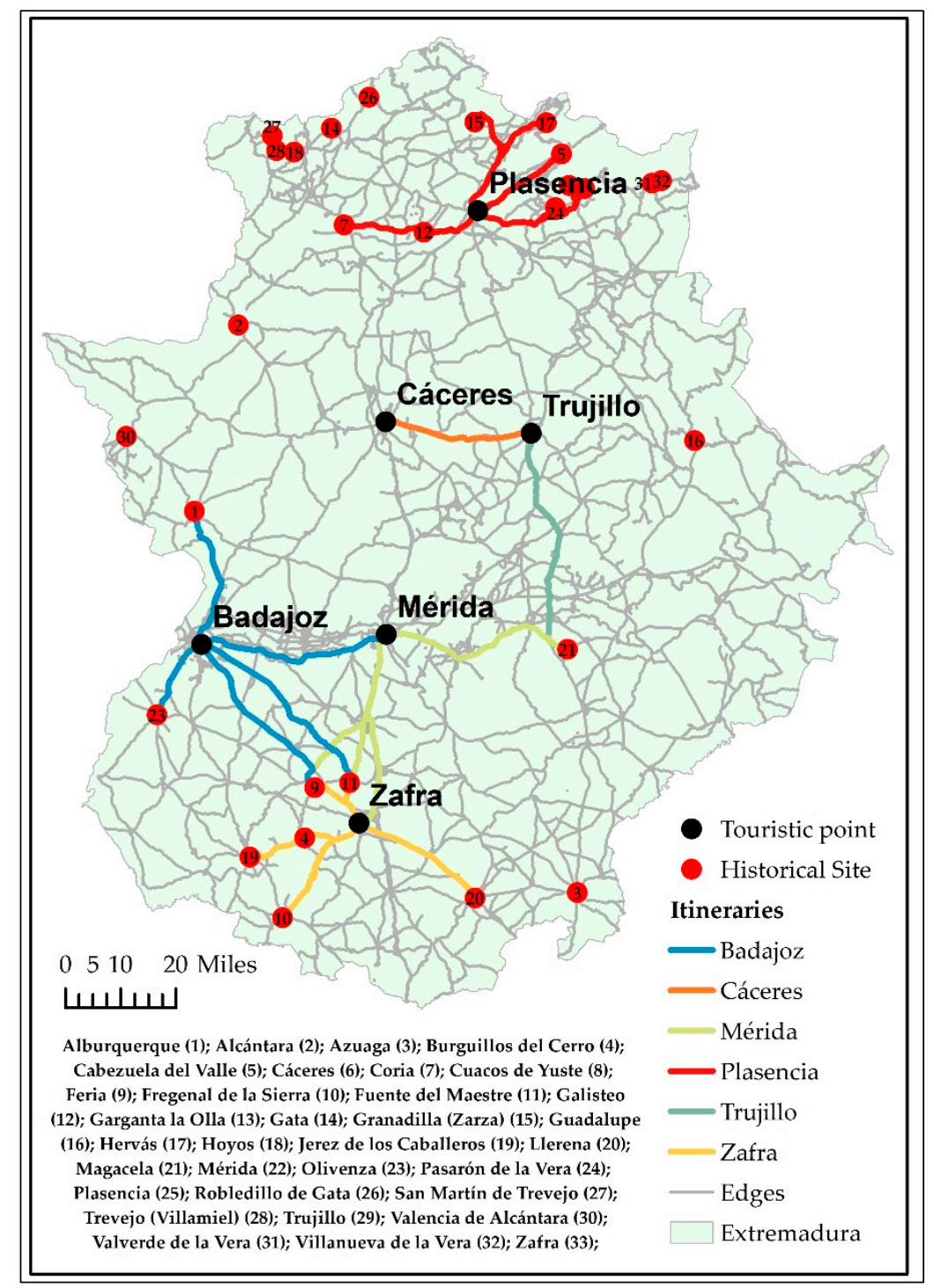

Figure 9. Design of tourist itineraries to Historical Ensembles from the main tourist centers.

The remainder of the overnight stay places can also benefit from the creation of specific itineraries; those that are already Historical Ensembles have competitive advantages as they attract a specific demand which is that of cultural tourism (Table 8). This is the case of Guadalupe, Hervás, Jerez de los Caballeros, Olivenza, and Valencia de Alcántara. Nevertheless, the travel time necessary to reach other historical places must also be taken into account.

A detailed analysis of the 84 itineraries obtained from the 16 secondary tourist points reflects a differentiated casuistry. Perhaps the most noteworthy aspect is that many itineraries involved relatively lengthy travel, which often exceeds the isochrone of $45 \mathrm{~min}$ such as those of Caminomorisco and Guadalupe. Despite this, some itineraries were very well marked such as those that can be generated between Alange and Mérida, which are part of the Roman Archaeological Site of Mérida and are barely 26 min apart. Other cases of very short routes are those between Baños de Montemayor and Hervás (8 $\mathrm{min}$ ); Don Benito and Magacela (14 min); Jerte or Navaconcejo and Cabezuela del Valle (5-6 min), and Malpartida de Plasencia and Galisteo or Plasencia (14-16 min). 
Table 8. Secondary itineraries.

\begin{tabular}{|c|c|c|c|c|c|}
\hline Tourist Point & Historical Ensemble & Min. & Tourist Point & Historical Ensemble & Min \\
\hline \multirow{5}{*}{ Alange } & Mérida & 26 & \multirow{7}{*}{ Jerez de los Caballeros } & Jerez de los Caballeros & 0 \\
\hline & Fuente del Maestre & 42 & & Burguillos del Cerro & 21 \\
\hline & Zafra & 48 & & Fregenal de la Sierra & 21 \\
\hline & Magacela & 57 & & Zafra & 39 \\
\hline & Feria & 58 & & Feria & 42 \\
\hline \multirow{6}{*}{ Almendralejo } & Fuente del Maestre & 23 & & Fuente del Maestre & 52 \\
\hline & Mérida & 23 & & Olivenza & 59 \\
\hline & Zafra & 29 & \multirow{5}{*}{ Jerte } & Cabezuela del Valle & 6 \\
\hline & Feria & 35 & & Plasencia & 45 \\
\hline & Burguillos del Cerro & 47 & & Hervás & 52 \\
\hline & Llerena & 54 & & Pasarón de la Vera & 56 \\
\hline \multirow{4}{*}{ Baños de Mont. } & Hervás & 8 & & Galisteo & 60 \\
\hline & Granadilla & 29 & \multirow{10}{*}{$\begin{array}{l}\text { Malpartida de } \\
\text { Plasencia }\end{array}$} & Galisteo & 14 \\
\hline & Plasencia & 37 & & Plasencia & 16 \\
\hline & Galisteo & 39 & & Pasarón de la Vera & 25 \\
\hline \multirow{8}{*}{ Caminomorisco } & Gata & 44 & & Coria & 30 \\
\hline & Granadilla & 46 & & Hervás & 35 \\
\hline & Trevejo & 47 & & Cuacos de Yuste & 41 \\
\hline & Hoyos & 48 & & Granadilla & 41 \\
\hline & Hervás & 50 & & Cabezuela del Valle & 46 \\
\hline & Plasencia & 50 & & Garganta la Olla & 55 \\
\hline & Robledillo de Gata & 51 & & Hoyos & 57 \\
\hline & Coria & 53 & \multirow{6}{*}{ Monesterio } & Zafra & 32 \\
\hline \multirow{3}{*}{ Don Benito } & Magacela & 16 & & Llerena & 36 \\
\hline & Mérida & 45 & & Fuente del Maestre & 44 \\
\hline & Trujillo & 47 & & Fregenal de la Sierra & 45 \\
\hline Guadalupe & Guadalupe & 0 & & Burguillos del Cerro & 50 \\
\hline \multirow{7}{*}{ Hervás } & Hervás & 0 & & Feria & 51 \\
\hline & Granadilla & 27 & \multirow{7}{*}{ Navaconcejo } & Cabezuela del Valle & 5 \\
\hline & Plasencia & 34 & & Plasencia & 35 \\
\hline & Galisteo & 37 & & Pasarón de la Vera & 41 \\
\hline & Coria & 53 & & Galisteo & 50 \\
\hline & Cabezuela del Valle & 54 & & Garganta la Olla & 54 \\
\hline & Pasarón de la Vera & 60 & & Hervás & 57 \\
\hline \multirow{10}{*}{ Jarandilla de la Vera } & Cuacos de Yuste & 14 & & Cuacos de Yuste & 58 \\
\hline & Valverde de la Vera & 22 & \multirow{3}{*}{ Olivenza } & Olivenza & 0 \\
\hline & Garganta la Olla & 26 & & Feria & 55 \\
\hline & Villanueva de la Vera & 26 & & Jerez de los Caballeros & 59 \\
\hline & Pasarón de la Vera & 34 & \multirow{3}{*}{ Torrejón el Rubio } & Trujillo & 36 \\
\hline & Plasencia & 60 & & Galisteo & 52 \\
\hline & & & & Plasencia & 54 \\
\hline & & & \multirow{3}{*}{ Valencia de Alc. } & Valencia de Alcántara & 0 \\
\hline & & & & Alburquerque & 37 \\
\hline & & & & Alcántara & 55 \\
\hline
\end{tabular}

Together, it can be seen that other itineraries explore the district of La Vera starting from Jarandilla de la Vera and with their final destination being five Historical Sites on routes with a travel time of about $30 \mathrm{~min}$. At the other extreme, we have Caminomorisco, which is at least $45 \mathrm{~min}$ from any other place of historical interest.

The territorial distribution showed two major concentrations of viable itineraries corresponding to the north of the province of Cáceres and the south of Badajoz. This circumstance may favor the creation of longer itineraries and in this way fight against the short average stay, which characterizes most of the tourist accommodation of both spaces. On the other hand, it was also shown that some Historical Ensembles are not part of the circuits as their travel times exceed one hour, as in the case of 
Guadalupe and Azuaga. Likewise, other itineraries can be appreciated, which are very isolated in the territory; the most representative case is that of Valencia de Alcántara (Figure 10).

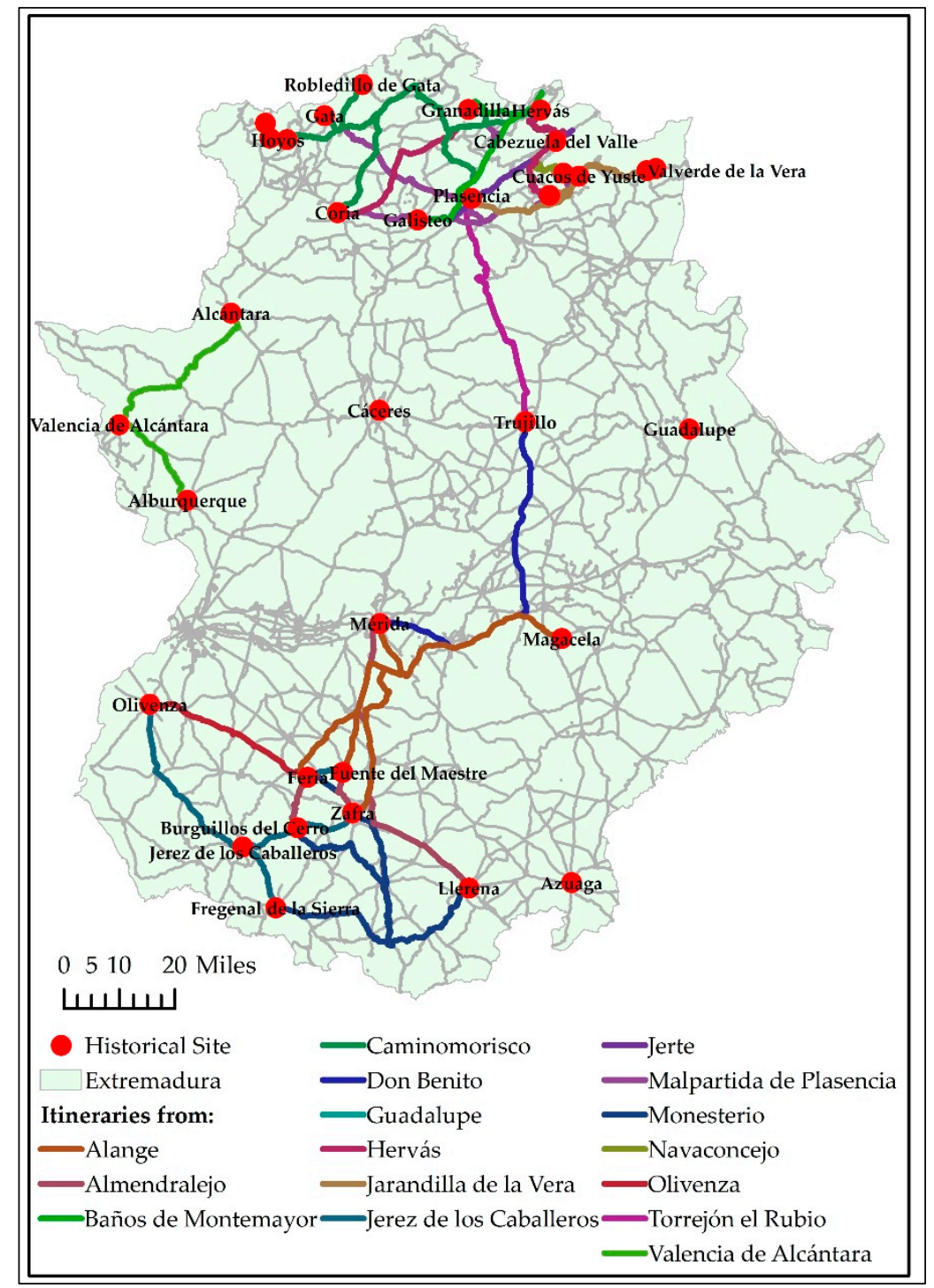

Figure 10. Design of tourist itineraries to Historical Ensembles from the main tourist centers.

\section{Discussion}

The rapid implementation of technological advances is becoming more and more relevant in cultural tourism. Numerous studies incorporate conceptual models designed to improve tourist experiences by means of immersive technology $[93,94]$ such as augmented reality $[95,96]$. Use is also made of the analysis of the information provided by social networks to detect mobility patterns [97].

It is obvious that there is a strong technological bid for the development and improvement of tourist experiences. However, few studies have explored methods for generating tourist itineraries to which the technological innovations mentioned are subsequently applied [44,45]. To a certain extent, the impression given is that the itineraries arise spontaneously, without taking into account other criteria regarding the specific demand of each territory and the time available or the necessary travel. Perhaps more importance is attached to the technique than basic knowledge when the reverse should be true.

Given this situation, the research proposes a methodology that allows for the creation of itineraries, taking as basis criteria the proximity and travel time, in addition to the presence of resources. In order 
to demonstrate its potential, we have taken as a basis a specific area that counts on a peculiar kind of resource, Historical Ensembles. Numerous studies emphasize that this kind of tourist attraction can capture a large number of visitors and day trippers. In order to achieve this, it is necessary to create specific itineraries that offer the potential tourist the possibility of getting to know the nearby heritage in a coordinated manner by means of a tourist product. This idea has been put forward by numerous authors at very different times [98-101], and is of particular interest in areas with a considerable scattered cultural heritage that are not in themselves capable of attracting numerous tourists.

In the context analyzed, the creation of itineraries arises as a basic need for encouraging tourism as can be seen on numerous official websites, although an exhaustive classification of these has not been carried out in the study area [102]. On occasion, the itineraries do not arise from specific analyses based on methods, but are rather the result of improvisation [45] or do not even exist. A lack of the same constitutes a clear limitation of the development of the activity [103] as they may form cultural corridors to multiply the added value of a destination. This aspect is essential when the resources are not sufficiently attractive to generate tourist flows and must be supported by other resources, if they are to be competitive and capture visitors. As a consequence, the study carried out aims to lay the foundations of what may be a valid methodology for highlighting the cultural heritage of many areas. In order to achieve this, we resorted to a GIS, a tool frequently used in the analysis, management, and planning of tourism [104-106]. To be precise, the study concentrated on the use of the network analyst, a specific tool that allows for the calculation of service areas and the closest facility. Both analyses generate itineraries starting from a series of facilities and incidents to facilitate decision-making and tourist management.

The application of the network analyst allows for the creation of numerous routes and their prioritizing in accordance with the criteria indicated, either because of the importance of the tourist point from which they start, or the proximity of other potential destinations. It is therefore made clear that not all of the possible routes will be viable due to the necessary travel time, which means that they are limited. This shows that it is possible to generate tourist itineraries on which to begin studies of economic viability and to promote the creation of products that combine experiences in different places. From these, it will be possible to apply all the technological innovations that are beginning to become widespread in the tourist sector such as augmented reality, big data [107], and even artificial intelligence [108].

The results obtained in this study show that it is possible to create itineraries, provided that certain minimum conditions are met such as being aware of the location of the resources and the main centers of tourist attraction as well as the road network. In its turn, with the introduction of the necessary adjustments, it is possible to reproduce the methodology with other tourist resources and in other places. It was corroborated that Historical Ensembles are centers of tourist attraction that can benefit from joint interaction by the implementation of tourist itineraries. Likewise, it is emphasized that it is possible to manage and plan these itineraries by adjusting the selection criteria, either of the kind of resource or the travel time that tourists wish to devote to getting to know the vicinity.

The usefulness of this research is focused on demonstrating the potential of Extremadura for the creation of cultural itineraries and facilitation of the comprehensive management of the same. It thus aims to be a work base on which to encourage the tourist development of rural areas by highlighting their cultural heritage. For this reason, numerous actions are necessary to create products orientated toward excursions, which are offered at the main points of tourist attraction. Subsequently, it will be necessary to create products focusing on tourists spending the night at the various points that make up an itinerary.

The results obtained open up future lines of research involving ascertaining the preferences of demand in such a way that the generation of itineraries based on specific resources can be further specified. In this case, the methodology would clear the way for the creation of itineraries based on castles, megaliths, etc. In the same manner, another line could be opened up to lead to the generation 
of products highlighting the itineraries created to feature the availability of accommodation and restaurants, tourist guides, etc.

\section{Conclusions}

The main conclusions that can be drawn from this research are diverse.

The first reveals that although the type of tourists who visit Extremadura varies greatly, they can clearly be placed in two categories: those with cultural preferences and those who identify with the natural milieu. Moreover, the territorial distribution does not always adapt to the presence of certain resources. It has thus been detected that some areas contain a considerable cultural heritage, but cultural tourists do not predominate there, which casts a doubt as to whether their tourist exploitation is satisfactory.

The second shows that the cultural heritage of Extremadura is one of the essential resources for tourist development. Despite the extraordinary richness of the heritage, only a few tourist centers are capable of highlighting it. Indeed, these tourist points are noted for their capacity of capturing tourists and are characterized by being Historical Ensembles, although the most outstanding are the World Heritage Sites of Cáceres and Mérida. It can, however, be appreciated that other centers exist, which do not attract a significant volume of visitors, despite the fact that they are Historical Ensembles.

The third stresses the need to create tourist itineraries capable of multiplying the attraction of certain centers, which is necessary when a single municipality is incapable of attracting visitors on its own accord. The creation of these itineraries is always complex and on occasion, may be ambiguous; indeed some authors maintain that tourist routes themselves may be both a resource and a product $[109,110]$. Nevertheless, the study has shown that cultural tourism is particularly attractive in Extremadura as is borne out by the large number of tourists and overnight stays recorded in its main heritage towns. For this reason, it is thought necessary to stress the expansion of the development of activity toward areas that are not on the tourist market.

The fourth shows the use of GISs to generate these itineraries, taking as a basic tool the network analyst and combining the analytical possibilities it offers. There is no doubt that GIS tools have become very popular for the analysis and management of the territory, especially when they offer a huge potential for facilitating the taking of decisions. Indeed precedents exist that defend their role as a management tool [111,112] and as necessary software for the creation of tourist itineraries and the discovery of mobility patterns [44,70]. Likewise, it has been stressed that it is a simple matter to create tourist itineraries by using these network analysis tools, but it cannot be denied that it is also possible to develop the routes much further to adapt them to the requirements considered appropriate by managers. In this sense, both the closest facility and the service area tool have been shown to be efficient.

The fifth concentrates on the discrimination of itinerary types taking into account basic aspects of the origin and the destination in addition to the travel time. If the essential results are considered, it is clear that there are areas in which it is very easy to generate and highlight an itinerary when some Historical Ensembles are a very short distance from others. In contrast, other areas find it very difficult to establish routes due to their peripheral position or their poor accessibility, which means that they depend on their own action to capture tourists.

The sixth and last conclusion that can be drawn is the need to establish as a starting point the design of itineraries to offer competitive products in areas that are not in the best position for tourism due to external determinants such as their location or accessibility [113]. Naturally, the final design of the itinerary and its conversion into a resource needs further study to measure the attraction capacity of the territory using specific assessment techniques for both demand and supply.

Author Contributions: Conceptualization, José-Manuel Sánchez-Martín, María-José García-Berzosa, and José-Luis Gurría-Gascón; Methodology, José-Manuel Sánchez-Martín; Formal analysis, José-Manuel Sánchez-Martín and José-Luis Gurría-Gascón; Investigation, José-Manuel Sánchez-Martín; Resources, José-Manuel Sánchez-Martín; Data curation: José-Manuel Sánchez-Martín and María-José García-Berzosa; Writing—original draft preparation, 
José-Manuel Sánchez-Martín, María-José García-Berzosa, and José-Luis Gurría-Gascón; Writing-review and editing, José-Manuel Sánchez-Martín, María-José García-Berzosa, and José-Luis Gurría-Gascón; Supervision, José-Manuel Sánchez-Martín. and José-Luis Gurría-Gascón; Project administration, José-Manuel Sánchez-Martín; Funding acquisition, José-Manuel Sánchez-Martín. All authors have read and agreed to the published version of the manuscript.

Funding: This publication is part of the research carried out within the research project "Diseño y elaboración de productos estratégicos diferenciados para la potenciación del turismo rural en Extremadura. De la detección de problemas a la propuesta de soluciones basadas en criterios geoestadísticos" (Code IB 16040). This Project was funded by the Consejería de Economía e Infraestructuras de la Junta de Extremadura (the branch of the regional government that covers economy and infrastructure) and by the European Regional Development Fund (ERDF). This work was supported by Junta of Extremadura and co-financed by the European Regional Development Fund through GR18052 (DESOSTE).

Conflicts of Interest: The authors declare no conflicts of interest.

\section{References}

1. Prats, L. El concepto de patrimonio cultural. Política Soc. 1998, 27, 63-76.

2. Vecco, M. A definition of cultural heritage: From the tangible to the intangible. J. Cult. Herit. 2010, 11, 321-324. [CrossRef]

3. García, N. Culturas Hibridas: Estrategias para Entrar y Salir de la Modernidad; Paidós: Buenos Aires, Argentina, 2005; 349p.

4. Prats, L.; Santana, A. Reflexiones libérrimas sobre patrimonio, turismo y sus confusas relaciones. In El Encuentro del Turismo con el Patrimonio Cultural: Concepciones Teóricas y Modelos de Aplicación; Prats, L., Santana, A., Eds.; Fundación El Monte: Sevilla, Spain, 2005; pp. 9-25.

5. Fontal, O. La educación patrimonial. Teoría y Práctica en el Aula, el Museo e Internet; Trea: Gijón, España, 2004; p. 303.

6. Whelan, Y. Heritage, Memory and the Politics of Identity: New Perspectives on the Cultural Landscape; Routledge: New York, NY, USA, 2007; 168p. [CrossRef]

7. Barthel, D. Cultural Heritage and the Challenge of Sustainability; Routledge: New York, NY, USA, 2016; 222p.

8. Larsen, P.B.; Logn, W. World Heritage and Sustainable Development. New Directions in World Heritage Management; Routledge: London, UK, 2018; 310p.

9. González, I. Conservación de Bienes Culturales. Teoría, Historia, Principios y Normas; Cátedra: Madrid, Spain, 2006; 632p.

10. Yu, X.; Xu, H. Cultural heritage elements in tourism: A tier structure from a tripartite analytical framework. J. Destin. Mark. Manag. 2019, 13, 39-50. [CrossRef]

11. Zamora, E. Sobre patrimonio y desarrollo. Aproximación al concepto de patrimonio cultural y su utilización en procesos de desarrollo territorial. 1, 2011, Pasos. Rev. Tur. Patrim. Cult. 2011, 9, 101-113. [CrossRef]

12. Fernández, E. De tesoro ilustrado a recurso turístico: El cambiante significado del patrimonio cultural. Pasos. Rev. Tur. Patrim. Cult. 2006, 4, 1-12. [CrossRef]

13. Timothy, D.J.; Nyaupane, G.P. Cultural Heritage and Tourism in the Developing World; Routledge: London, UK, 2009; 280p. [CrossRef]

14. de la Calle, M.; García, M. Ciudades históricas: Patrimonio cultural y recurso turístico. Ería 1998, 47, $249-266$. Available online: https://dialnet.unirioja.es/descarga/articulo/34879.pdf (accessed on 15 December 2019).

15. Troitiño, M.A. Turismo y ciudades históricas. Retos y oportunidades. Tur. Patrim. 2000, 1, 27-34. [CrossRef]

16. Castro, B.; Lois, R.C.; Lopez, L.; Ahmad, R.; Hertzog, A. Historic city, tourism performance and development: The balance of social behaviours in the city of Santiago de Compostela (Spain). Tour. Hosp. Res. 2016, 16, 282-293. [CrossRef]

17. Olivera, A. Patrimonio inmaterial, recurso turístico y espíritu de los territorios. Cuad. Tur. 2001, 27, 663-677. Available online: https://revistas.um.es/turismo/article/view/140151/126251 (accessed on 12 December 2019).

18. Hernández, J. Los caminos del patrimonio. Rutas e itinerarios culturales. Pasos. Rev. Tur. Patrim. Cult. 2011, 9, 225-236. [CrossRef]

19. Porcal, M.C. El patrimonio rural como recurso turístico. La puesta en valor turístico de infraestructuras territoriales (rutas y caminos) en las áreas de montaña del País Vasco y de Navarra. Cuad. Tur. 2011, 27,759-784. Available online: https://revistas.um.es/turismo/article/view/140211/126361 (accessed on 19 December 2019). 
20. Cañizares, M.C. La "Ruta de Don Quijote" en Castilla-La Mancha (España): Nuevo itinerario cultural europeo. Nimbus 2008, 21-22, 55-75. Available online: http://repositorio.ual.es/bitstream/handle/10835/1510/ Ca\%C3\%B1izares\%20Ruta.pdf?sequence=1 (accessed on 1 December 2019).

21. Ghimire, K.B.; Pimbert, M.P. Social change and conservation; Earthscan: London, UK, 2008; 341p.

22. Harrison, D.; Hitchconck, M. The Politics of World Heritage. Negotiating Tourism and Conservation; Channel View Publications: Bristol, UK, 2005; 192p.

23. Dallen, J.T.; Gyan, P.N. Cultural Heritage and Tourism in the Developing World: A Regional Perspective; Routledge: London, UK, 2009.

24. Troitiño Vinuesa, M.A.; Troitiño Torralba, L. Patrimonio y turismo: Reflexión teórico-conceptual y una propuesta metodológica integradora aplicada al municipio de Carmona (Sevilla, España). Scr. Nova 2019, 20, 1-45. Available online: http://www.ub.edu/geocrit/sn/sn-543.pdf (accessed on 27 February 2020). [CrossRef]

25. Brandis, D. La imagen cultural y turística de las Ciudades Españolas Patrimonio de la Humanidad. In Ciudades Patrimonio de la Humanidad: Patrimonio, Turismo y Recuperación Urbana; Troitiño, M.A., Ed.; Universidad Internacional de Andalucía/Junta de Andalucía: Sevilla, Spain, 2009; pp. 72-99.

26. Collin Harguindeguy, L. La transformación del patrimonio cultural en recurso turístico. Rev. Andal. Antropol. 2019, 16, 21-48. [CrossRef]

27. Prats, F. Sostenibilidad y turismo, una simbiosis imprescindible. Estud. Turísticos 2007, 173, 13-66. Available online: http://www.iet.tourspain.es/img-iet/revistas/ret-172-173-2007-pag13-62-101045.pdf (accessed on 27 February 2020).

28. Loulanski, T.; Loulanski, V. The sustainable integration of cultural heritage and tourism: A meta-study. J. Sustain. Tour. 2011, 19, 837-862. [CrossRef]

29. Li, Y. Heritage tourism: The contradictions between conservation and change. Tour. Hosp. Res. 2003, 4, 247-261. [CrossRef]

30. Liu, Z. Sustainable tourism development: A critique. J. Sustain. Tour. 2003, 11, 459-475. [CrossRef]

31. Kelman, I. Critiques of island sustainability in tourism. Tour. Geogr. 2019, 1-18. [CrossRef]

32. Crespi, M.; Planells, M. Recursos turísticos; Síntesis: Madrid, Spain, 2011; 424p.

33. Martos, M. Las ciudades patrimoniales en el mercado turístico cultural. Úbeda y Baeza. Gran Tour. Rev. Investig. Turísticas 2012, 6, 63-82. Available online: https://dialnet.unirioja.es/descarga/articulo/4172823.pdf (accessed on 27 December 2019).

34. González, S.; Querol, M.A. El patrimonio inmaterial. Rev. PH 2015, 88, 306-307. Available online: http://www.iaph.es/revistaph/index.php/revistaph/article/view/3626/3697 (accessed on 5 December 2019).

35. Rengifo, J.I. Rutas culturales y turismo en el contexto español. PH Boletín Inst. Andal. Patrim. 2006, 60, 114-125. Available online: http://www.iaph.es/revistaph/index.php/revistaph/article/view/2263/2263 (accessed on 5 December 2019). [CrossRef]

36. Cisne, R.; Gastal, S. Nueva visión sobre los itinerarios turísticos. Una contribución a partir de la complejidad. Estud. Y Perspect. En Tur. 2011, 20, 1449-1463. Available online: http://www.redalyc.org/pdf/1807/180722700012.pdf (accessed on 5 December 2019).

37. Mascarenhas, R.G.; Gândara, J.M. Producción y transformación territorial. La gastronomía como atractivo turístico. Estud. Perspect. Tur. 2010, 19, 776-791. Available online: https://dialnet.unirioja.es/descarga/ articulo/3352414.pdf (accessed on 5 December 2019).

38. Boletín Oficial del Estado (BOE). Código Civil y Legislación Complementaria. Available online: https://www. boe.es/legislacion/codigos/codigo.php?id=034_Codigo_Civil_y_legislacion_complementaria (accessed on 2 November 2019).

39. Boletín Oficial del Estado (BOE). Ley 13/85 del Patrimonio Histórico Español. Available online: https: //www.boe.es/boe/dias/1985/06/29/pdfs/A20342-20352.pdf (accessed on 2 November 2019).

40. Ministerio de Cultura y Deporte. Gobierno de España. Base de datos de Bienes Muebles. Available online: https://www.culturaydeporte.gob.es/bienes/cargarFiltroBienesMuebles.do?layout= bienesMuebles\&cache=init\&language=es (accessed on 2 November 2019).

41. Ministerio de Cultura y Deporte. Gobierno de España. Base de datos de Bienes Inmuebles. Available online: https:/www.culturaydeporte.gob.es/bienes/cargarFiltroBienesInmuebles.do?layout= bienesInmuebles\&cache $=$ init\&language $=$ es (accessed on 2 November 2019).

42. Boletín Oficial del Estado (BOE). Ley 45/2007, para el desarrollo sostenible del medio rural. Available online: https://www.boe.es/eli/es/1/2007/12/13/45/con (accessed on 2 November 2019). 
43. Sánchez, J.M.; Sánchez, M. Sinergias turísticas en entornos rurales: Entre el mito y la realidad. El caso del Geoparque Villuercas-Ibores-Jara. In X Citurdes: Congreso Internacional de Turismo Rural y Desarrollo Sostenible, Santiago de Compostela, Spain, 19-21 October 2016; Santos, X.M., Taboada, P., Lopez, L., Eds.; UFRGS, USC, ANTE, Grupo Mercados Nâo Agrícolas Rurais: Santiago de Compostela, Spain, 2016; pp. 433-448.

44. Sánchez, J.M.; Rengifo, J.I. Los espacios naturales protegidos y su capacidad de atracción turística: Referencias al Parque Nacional de Monfragüe (Extremadura-España). In Proceedings of the APDR; Universidade de Beira Interior; RSAI; ERSA, Intellectual Capital and Regional Development: New Landscapes and Challenges for Space Planning, Covilhâ, Portugal, 6-7 July 2017; pp. 1196-1206.

45. Sánchez, J.M.; Rengifo, J.I.; Martín, L.M. Tourist mobility at the destination toward protected areas: The case-study of extremadura. Sustainability 2018, 10, 4853. [CrossRef]

46. Sánchez, J.M.; Rengifo, J.I.; Sánchez, M. Caracterización espacial del turismo en Extremadura mediante análisis de agrupamiento (grouping analysis). Un ensayo técnico. Geofocus. Rev. Int. Cienc. Tecnol. Inf. Geográfica 2017, 19, 207-235. [CrossRef]

47. Sánchez, J.M.; Blas, R.; Rengifo, J.I. The dehesas of extremadura, Spain: A potential for socio-economic development based on agritourism activities. Forests 2019, 10, 620. [CrossRef]

48. Sánchez, J.M.; Sánchez, M.; Rengifo, J.I. La evaluación del potencial para el desarrollo del turismo rural. Aplicación metodológica sobre la provincia de Cáceres. Geofocus: Rev. Int. Cienc. Tecnol. Inf. Geográfica 2013, 13, 99-130. Available online: http://www.geofocus.org/index.php/geofocus/article/view/263 (accessed on 15 December 2019).

49. Rengifo, J.I.; Sánchez, J.M. El patrimonio en Extremadura: Un mecanismo para la cooperación transfronteriza. Polígonos. Rev. Geogr. 2017, 29, 223-248. Available online: http://revpubli.unileon.es/ojs/index.php/poligonos/ article/view/5207 (accessed on 15 December 2019). [CrossRef]

50. Su, R.; Bramwell, B.; Whalley, P.A. Cultural political economy and urban heritage tourism. Ann. Tour. Res. 2018, 68, 30-40. [CrossRef]

51. Srijuntrapun, P.; Fisher, D.; Rennie, H.G. Assessing the sustainability of tourism-related livelihoods in an urban World Heritage Site. J. Herit. Tour. 2018, 13, 395-410. [CrossRef]

52. García, M.; de la Calle, M.; Yubero, C. Cultural heritage and urban tourism: Historic city centres under pressur. Sustainability 2017, 9, 1346. [CrossRef]

53. Shoval, N. Urban planning and tourism in European cities. Tour. Geogr. 2018, 20, 371-376. [CrossRef]

54. Park, E.; Choi, B.K.; Lee, T.J. The role and dimensions of authenticity in heritage tourism. Tour. Manag. 2019, 74, 99-109. [CrossRef]

55. Logothetis, S.; Stylianidis, E. BIM open source software (OSS) for the documentation of cultural heritage. Virtual Archaeol. Rev. 2016, 7, 28-35. [CrossRef]

56. Tscheu, F.; Buhalis, D. Augmented reality at cultural heritage sites. In Information and Communication Technologies in Tourism; Inversini, A., Schegg, R., Eds.; Springer: Berlin/Heidelberg, Germany, 2016; pp. 607-619. [CrossRef]

57. Yovcheva, Z.; Buhalis, D.; Gatzidis, C. Engineering augmented reality tourism experiences. In Information and Communication Technologies in Tourism; Cantoni, L., Xiang, Z., Eds.; Springer International Publishing: Vienna, Austria, 2015; pp. 24-35. [CrossRef]

58. Bekele, M.; Pierdicca, R.; Frontoni, E.; Malinverni, E.; Gain, J. A survey of augmented, virtual, and mixed reality. J. Comput. Cult. Herit. 2018, 11, 1-36. [CrossRef]

59. Neuhofer, B.; Buhalis, D.; Ladkin, A. A typology of technology-enhanced tourism experiences. Int. J. Tour. Res. 2014, 16, 340-350. [CrossRef]

60. Naranjo, F.Z. La Convención Europea del Paisaje y su aplicación en España. Ciudad Territ. 2001, 128, $275-282$.

61. Council of Europe. 2008. Recomendación CM/Rec(2008)3 del Comité de Ministros a los Estados miembro sobre las orientaciones para la aplicación del Convenio Europeo del Paisaje. Available online: https://www.mapa.gob.es/es/desarrollo-rural/planes-y-estrategias/desarrollo-territorial/ 09047122800d2b4d_tcm30-421588.pdf (accessed on 27 February 2020).

62. Silva Pérez, R. La dehesa vista como paisaje cultural. Fisionomías, funcionalidades y dinámicas históricas. Ería 2010, 82, 143-157. Available online: https://www.unioviedo.es/reunido/index.php/RCG/article/view/ 1691/1585 (accessed on 27 February 2020).

63. Guzmán Álvarez, J.R. The image of a tamed landscape: Dehesa through history in Spain. Cult. Hist. Digit. J. 2016, 5, e003. [CrossRef] 
64. Fernández Cacho, S. La dimensión paisajística en la gestión del patrimonio cultural en España. Estud. Geográficos 2019, 80, 1-16. [CrossRef]

65. Cruz Pérez, L. El agua como elemento generador de paisajes culturales: Una visión desde el Plan Nacional de Paisaje Cultural. In Paisajes Culturales del Agua; Lozano Bartolozzi, M.M., Méndez Hernán, V., Eds.; Universidad de Extremadura: Cáceres, Spain, 2017; pp. 17-36. Available online: http:// dehesa.unex.es/bitstream/handle/10662/6703/978-84-697-4487-1.pdf?sequence=1\&isAllowed=y (accessed on 27 February 2020).

66. Naranjo, F.Z. Los paisajes como patrimonio natural y cultural. In I Congreso Internacional "El Patrimonio cultural y natural como motor de desarrollo: Investigación e innovación"; Peinado Herreros, M.A., Ed.; Universidad Internacional de Andalucía: Seville, Spain, 2012; pp. 626-644. Available online: http://dspace.unia.es/ bitstream/handle/10334/3456/2012_Congresointernacional.pdf (accessed on 27 February 2020).

67. Fanfani, D.; Matarán Ruiz, A. La aplicación del Convenio Europeo del Paisaje en España e Italia: Un análisis crítico de los casos andaluz y toscano. Rev. Electrónica Patrim. Histórico 2010, 6, 1-15. Available online: https://revistaseug.ugr.es/index.php/erph/article/view/3372/3384 (accessed on 27 February 2020).

68. Rengifo, J.I.; Sánchez, J.M. Atractivos naturales y culturales vs. desarrollo turístico en la raya Luso-Extremeña. Pasos: Rev. Tur. Patrim. Cult. 2016, 14, 907-928. [CrossRef]

69. Instituto Nacional de Estadística. Hoteles: Encuesta de ocupación, índice de precios e indicadores de rentabilidad. Available online: https://www.ine.es/dynt3/inebase/es/index.htm?padre=238\&dh=1 (accessed on 25 March 2019).

70. Sánchez-Martín, J.-M.; Sánchez-Rivero, M.; Rengifo-Gallego, J.-I. Water as a tourist resource in Extremadura: Assessment of its attraction capacity and approximation to the tourist profile. Sustainability 2020, 12, 1659. [CrossRef]

71. Instituto Geográfico Nacional (IGN). Available online: http://www.ign.es/web/resources/docs/IGNCnig/ CBG\%20-\%20BTN100.pdf (accessed on 2 November 2019).

72. Junta de Extremadura. Extremadura Turismo. Available online: http://www.turismoextremadura.com/es/ organiza-tu-viaje/donde-alojarse/index.html (accessed on 2 November 2019).

73. Mckercher, B.; Lau, G. Movement patterns of tourists within a destination. Tour. Geogr. 2008, 10, 355-374. [CrossRef]

74. Zoltan, J.; McKercher, B. Analysing intra-destination movements and activity participation of tourists through destination card consumption. Tour. Geogr. 2015, 17, 19-35. [CrossRef]

75. Zhong, L.; Sun, S.; Law, R. Movement patterns of tourists. Tour. Manag. 2019, 75, 318-322. [CrossRef]

76. Chante, A.; Fuentes, L.; Muñoz, A.; Ramírez, G. Science mapping of tourist mobility 1980-2019. technological advancements in the collection of the data for tourist traceability. Sustainability 2019, 11, 4738. [CrossRef]

77. Viamichelin. Available online: https://www.viamichelin.es (accessed on 2 November 2019).

78. Indriasari, V.; Mahmud, A.; Anmad, N.; Shariff, A. Maximal service area problem for optimal siting of emergency facilities. Int. J. Geogr. Inf. Sci. 2010, 24, 213-230. [CrossRef]

79. Liu, L.; Xia, B.; Wu, H.; Zhao, J.; Peng, Z.; Yu, Y. Delimitating the natural city with points of interests based on service area and maximum entropy method. Entropy 2019, 21, 458. [CrossRef]

80. Wang, J.; Kwan, M.P. Hexagon-based adaptive crystal growth voronoi diagrams based on weighted planes for service area delimitation. ISPRS Int. J. Geo-Inf. 2018, 7, 257. [CrossRef]

81. ESRI. Available online: https://desktop.arcgis.com/es/arcmap/latest/extensions/network-analyst/service-area. htm (accessed on 15 November 2019).

82. Love, D.; Lindquist, P. The geographical accessibility of hospitals to the aged: A geographic information systems analysis within Illinois. Health Serv. Res. 1995, 29, 629-651. Available online: https://go.gale.com/ps/i.do?id=GALE\%7CA16745151\&sid=googleScholar\&v=2.1\&it=r\& linkaccess $=$ fulltext\&issn $=00179124 \& \mathrm{p}=\mathrm{AONE} \& \mathrm{sw}=\mathrm{W}$ (accessed on 12 December 2019). [PubMed]

83. AwaghadeII, S.; DandekarI, P.; Ranade, P. Site selection and closest facility analysis for automated teller machine (ATM) centers: Case study for Aundh (Pune), India. Int. J. Adv. Remote Sens. GIS Geogr. 2014, 2, 19-29. Available online: http://citeseerx.ist.psu.edu/viewdoc/download?doi=10.1.1.671.562\&rep=rep1\&type=pdf (accessed on 12 December 2019).

84. Drezner, T. Locating a single new facility among existing, unequally attractive facilities. J. Reg. Sci. 1994, 34, 237-252. [CrossRef] 
85. ReVelle, C.S.; Eiselt, H.A. Location analysis: A synthesis and survey. Eur. J. Oper. Res. 2005, 165, 1-19. [CrossRef]

86. Instituto Nacional de Estadística (INE). Available online: http://www.ine.es/FichasWeb/RegComunidades. do?fichas $=49 \&$ busc_comu=\&botonFichas $=I r+a+l a+t a b l a+d e+$ resultados (accessed on 5 November 2019).

87. UNWTO. Tourism and Culture. Available online: https://www.unwto.org/tourism-and-culture (accessed on 15 February 2019).

88. Zhao, X.; Lu, X.; Liu, Y.; Lin, J.; An, J. Tourist movement patterns understanding from the perspective of travel party size using mobile tracking data: A case study of Xi'an, China. Tour. Manag. 2018, 69, 368-383. [CrossRef]

89. Lew, A.; McKercher, B. Modeling tourist movements: A local destination analysis. Ann. Tour. Res. 2006, 33, 403-423. [CrossRef]

90. Asero, V.; Gozzo, S.; Tomaselli, V. Building tourism networks through tourist mobility. J. Travel Res. 2015, 55, 751-763. [CrossRef]

91. Masiero, L.; Zoltan, J. Tourists intra-destination visits and transport mode: A bivariate probit model. Ann. Tour. Res. 2013, 43, 529-546. [CrossRef]

92. Sánchez, M. Anuario de Oferta y Demanda Turística de Extremadura por Territorios. Año 2017; Junta de Extremadura: Mérida, Spain, 2018; 87p, Available online: https:/www.turismoextremadura.com/ .content/observatorio/2017/EstudiosYMemoriasAnuales/Anuario_oferta-demanda2017.pdf (accessed on 10 November 2019).

93. Bec, A.; Mayole, B.; Timms, K.; Schaffer, V.; Skavronskaya, L.; Little, C. Management of immersive heritage tourism experiences: A conceptual model. Tour. Manag. 2019, 72, 117-120. [CrossRef]

94. Yung, R.; Khoo, C. New realities: A systematic literature review on virtual reality and augmented reality in tourism research. Curr. Issues Tour. 2019, 22, 2056-2081. [CrossRef]

95. Tsai, S. Augmented reality enhancing place satisfaction for heritage tourism marketing. 2019. Curr. Issues Tour. 2019, 1-6. [CrossRef]

96. tom Dieck, M.C.; Jung, T. A theoretical model of mobile augmented reality acceptance in urban heritage tourism. Curr. Issues Tour. 2018, 21, 154-174. [CrossRef]

97. Ghermandi, A.; Camacho, V.; Trejo, H. Social media-based analysis of cultural ecosystem services and heritage tourism in a coastal region of Mexico. Tour. Manag. 2020, 77, 104002. [CrossRef]

98. Inskeep, E. Tourism planning: An emerging specialization. J. Am. Plan. Assoc. 1988, 54, 360-372. [CrossRef]

99. Hall, C.M. Tourism Planning: Policies, Processes and Relationships; Pearson: London, UK, 2008; 303p.

100. Mise, S. The role of spatial models in tourism planning. In New Metropolitan Perspectives. ISHT 2018. Smart Innovation, Systems and Technologies, 100; Calabrò, F., Della Spina, L., Bevilacqua, C., Eds.; Springer: Berlin/Heidelberg, Germany, 2019; pp. 105-112. [CrossRef]

101. Mrđa, A.; Carić, H. (2019) Models of heritage tourism sustainable planning. In Cultural Urban Heritage; The Urban Book Series; Obad Šćitaroci, M., Bojanić Obad Šćitaroci, B., Mrđa, A., Eds.; Springer: Berlin/Heidelberg, Germany, 2019; pp. 165-180. [CrossRef]

102. Calderón, D.M.; Arcila, M.L.; López, J.A. Las Rutas e Itinerarios Turístico-Culturales en los Portales Oficiales. Rev. De Estud. Andal. 2018, 35, 123-145. [CrossRef]

103. Shishmanova, M.V. Cultural tourism in cultural corridors, itineraries, areas and cores networked. Procedia-Soc. Behav. Sci. 2015, 188, 246-254. [CrossRef]

104. Mcadam, D. The value and scope of geographical information systems in tourism management. J. Sustain. Tour. 1999, 7, 77-92. [CrossRef]

105. Lee, S.-H.; Choy, J.-Y.; Yoo, S.-H.; Oh, Y.-G. Evaluating spatial centrality for integrated tourism management in rural areas using GIS and network analysis. Tour. Manag. 2013, 34, 14-24. [CrossRef]

106. Wei, W. Research on the application of geographic information system in tourism management. Procedia Environ. Sci. 2012, 12, 1104-1109. [CrossRef]

107. Inanc, M.; Kozak, M. Big data and its supporting elements: Implications for tourism and hospitality marketing. In Big Data and Innovation in Tourism, Travel, and Hospitality; Sigala, M., Rahimi, R., Thelwall, M., Eds.; Springer: Singapore, 2019; pp. 213-223. [CrossRef]

108. Astuti, K.A.; Darma, G.S. Community-based tourism: Measuring readiness of artificial intelligence on traditional village. Int. J. Soc. Sci. Humanit. 2019, 3, 81-89. [CrossRef] 
109. Torres Bernier, E. Rutas culturales. Recurso, destino y producto turístico. PH Boletín Del Inst. Andal. Del Patrim. Histórico 2006, 60, 84-97. Available online: http://www.iaph.es/revistaph/index.php/revistaph/article/ view/2259/2259 (accessed on 27 February 2020). [CrossRef]

110. Garrido, M.A.; Sánchez, J.L.; Enriquez, A.F. Rutas turísticos-culturales e itinerarios culturales como productos turísticos: Reflexiones sobre una metodología para su diseño y evaluación. In Análisis Espacial y Representación Geográfica: Innovación y Aplicación; de la Riva, J., Ibarra, P., Montorio, R., Rodrigues, M., Eds.; Universidad de Zaragoza: Aragon, Spain, 2015; pp. 463-471. Available online: http://congresoage.unizar.es/eBook/trabajos/ 049_Arcila\%20Garrido.pdf (accessed on 27 February 2020).

111. Sáenz Saavedra, N. Los sistemas de información geográfica (SIG) una herramienta poderosa para la toma de decisiones. Ing. E Investig. 1992, 28, 31-40. Available online: https://dialnet.unirioja.es/descarga/articulo/ 4902930.pdf (accessed on 27 February 2020).

112. Bosque Sendra, J. Planificación y gestión del territorio. De los SIG a los sistemas de ayuda a la decisión espacial (SADE). El Campo De Las Cienc. Y Las Artes 2001, 138, 137-174. Available online: https://geogra.uah. es/joaquin/pdf/SIG-y-SADE.pdf (accessed on 27 February 2020).

113. Sánchez, J.M.; Rengifo, J.I.; Sánchez, M. Protected areas as a center of attraction for visits from world heritage cities: Extremadura (Spain). Land 2020, 9, 47. [CrossRef]

(C) 2020 by the authors. Licensee MDPI, Basel, Switzerland. This article is an open access article distributed under the terms and conditions of the Creative Commons Attribution (CC BY) license (http://creativecommons.org/licenses/by/4.0/). 